\title{
Treatment and reuse of incineration bottom ash
}

T. Astrup (Technical University of Denmark)

A. Muntoni (University of Calgiari, Italy)

A. Polettini (University of Rome "La Sapienza", Italy)

T. van Gerven (Katholieke Universiteit Leuven, Belgie)

A. van Zomeren (ECN)

April 2016

ECN-B--16-004 


\section{ENVIRONMENTAL \\ MATERIALS AND WASTE \\ Resource Recovery and Pollution Prevention}

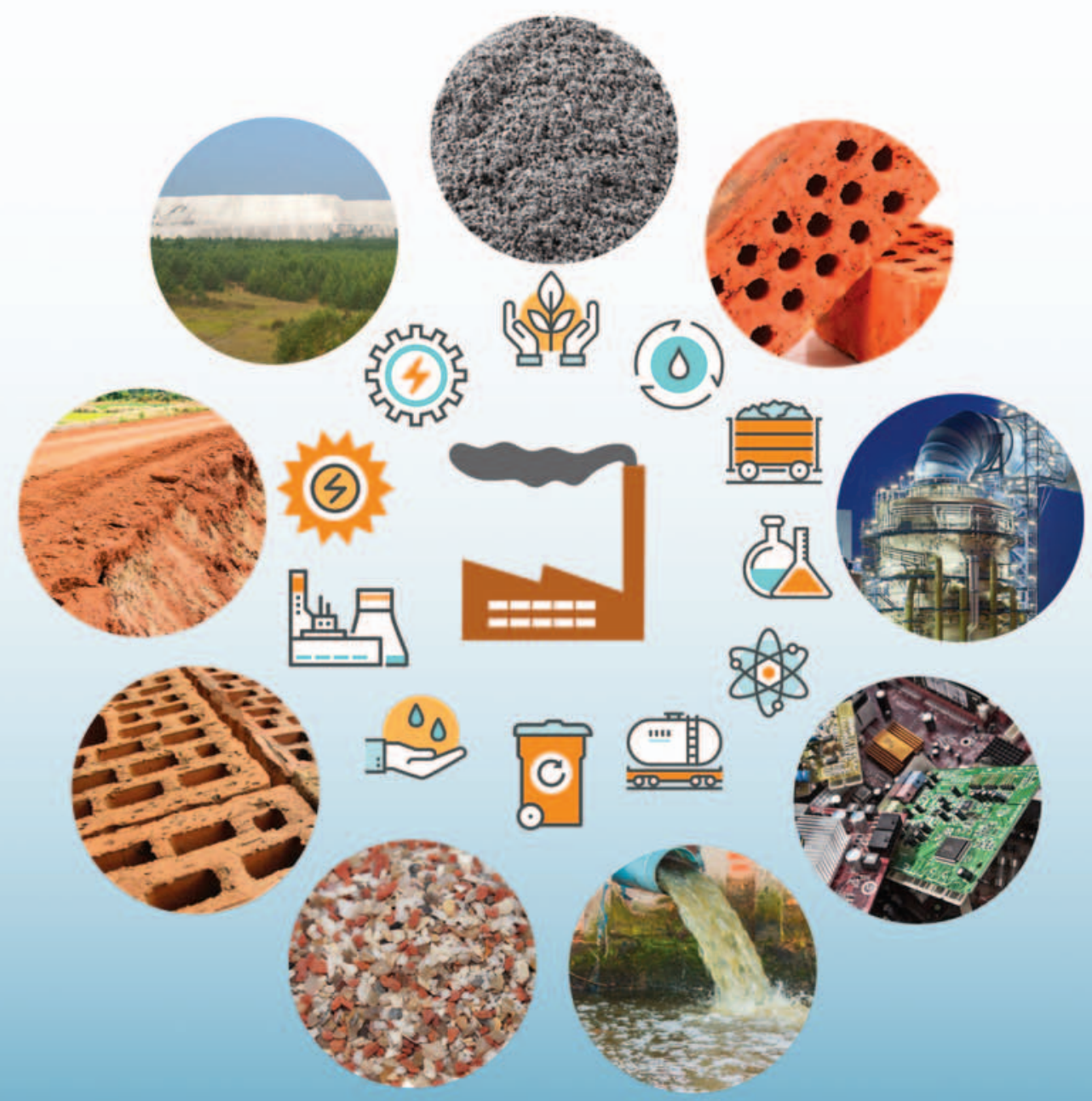

Edited by

M. N. V. Prasad \& Kaimin Shih

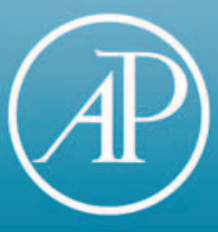




\section{Environmental Materials and Waste \\ Resource Recovery and Pollution \\ Prevention}


This page intentionally left blank 


\title{
Environmental Materials and Waste Resource Recovery and Pollution Prevention
}

Edited by

\author{
M.N.V. Prasad
}

Kaimin Shih
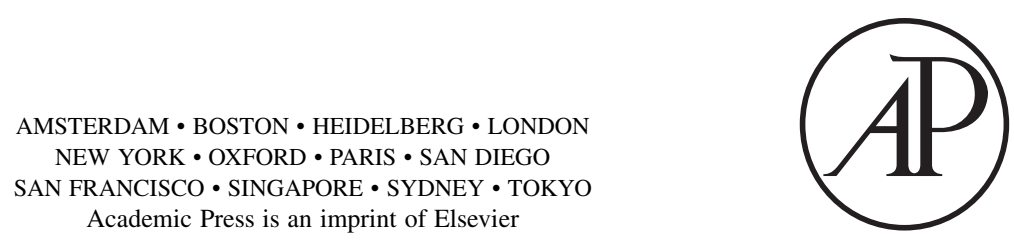
Academic Press is an imprint of Elsevier

125 London Wall, London EC2Y 5AS, UK

525 B Street, Suite 1800, San Diego, CA 92101-4495, USA

50 Hampshire Street, 5th Floor, Cambridge, MA 02139, USA

The Boulevard, Langford Lane, Kidlington, Oxford OX5 1GB, UK

Copyright @ 2016 Elsevier Inc. All rights reserved.

No part of this publication may be reproduced or transmitted in any form or by any means, electronic or mechanical, including photocopying, recording, or any information storage and retrieval system, without permission in writing from the publisher. Details on how to seek permission, further information about the Publisher's permissions policies and our arrangements with organizations such as the Copyright Clearance Center and the Copyright Licensing Agency, can be found at our website: www.elsevier.com/permissions.

This book and the individual contributions contained in it are protected under copyright by the Publisher (other than as may be noted herein).

\section{Notices}

Knowledge and best practice in this field are constantly changing. As new research and experience broaden our understanding, changes in research methods, professional practices, or medical treatment may become necessary.

Practitioners and researchers must always rely on their own experience and knowledge in evaluating and using any information, methods, compounds, or experiments described herein. In using such information or methods they should be mindful of their own safety and the safety of others, including parties for whom they have a professional responsibility.

To the fullest extent of the law, neither the Publisher nor the authors, contributors, or editors, assume any liability for any injury and/or damage to persons or property as a matter of products liability, negligence or otherwise, or from any use or operation of any methods, products, instructions, or ideas contained in the material herein.

\section{British Library Cataloguing-in-Publication Data}

A catalogue record for this book is available from the British Library

\section{Library of Congress Cataloging-in-Publication Data}

A catalog record for this book is available from the Library of Congress

ISBN: 978-0-12-803837-6

For information on all Academic Press publications visit our website at https://www.elsevier.com/

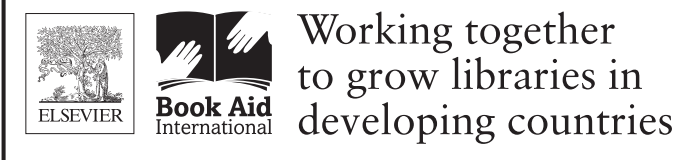 \\ www.elsevier.com • www.bookaid.org}

Publisher: Candice G. Janco

Acquisition Editor: Laura S Kelleher

Editorial Project Manager: Emily Thomson

Production Project Manager: Mohanapriyan Rajendran

Designer: Victoria Pearson

Typeset by TNQ Books and Journals 


\section{TREATMENT AND REUSE OF INCINERATION BOTTOM ASH}

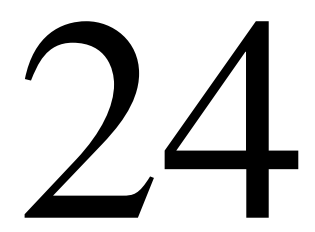

T. Astrup ${ }^{1}$, A. Muntoni ${ }^{2}$, A. Polettini ${ }^{3}$, R. Pomi ${ }^{3}$, T. Van Gerven ${ }^{4}$, A. Van Zomeren ${ }^{5}$

Technical University of Denmark, Lyngby, Denmark ${ }^{1}$; University of Cagliari, Cagliari, Italy ${ }^{2}$; University of Rome "La Sapienza," Rome, Italy ${ }^{3}$; Katholieke Universiteit Leuven, Leuven, Belgium ${ }^{4}$; Energy Research Centre of The Netherlands (ECN), Petten, The Netherlands ${ }^{5}$

\section{CHAPTER OUTLINE}

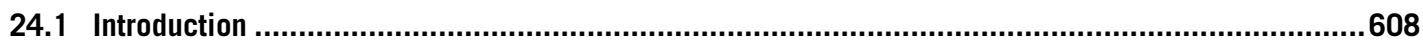

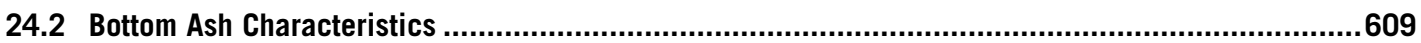

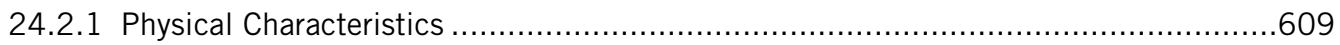

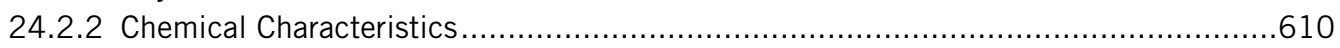

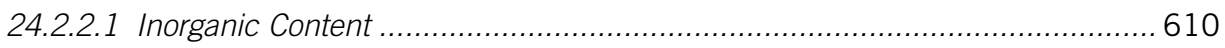

24.2.2.2 Organic Content.................................................................................. 613

24.2.2.3 Mineralogy and Geochemical Characteristics ............................................... 615

24.2.2.4 Leaching Behavior ........................................................................... 618

24.3 Bottom Ash Processing ...............................................................................................620

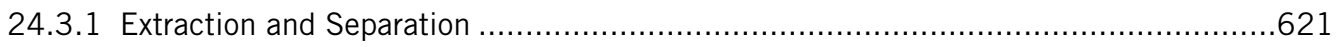

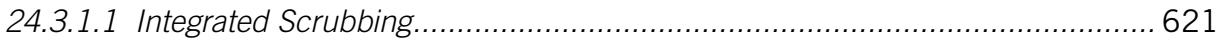

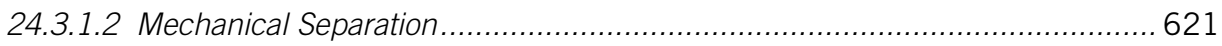

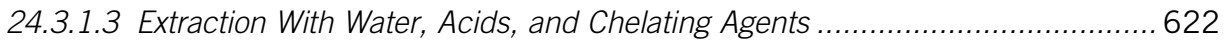

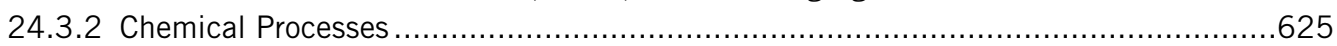

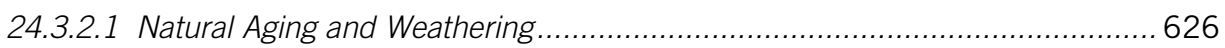

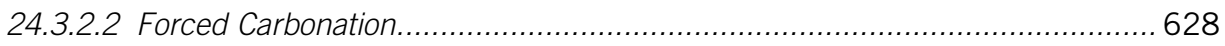

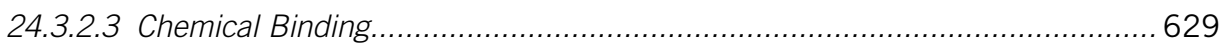

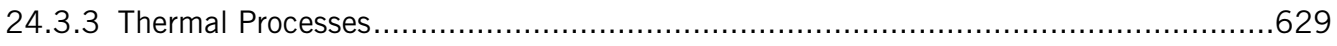

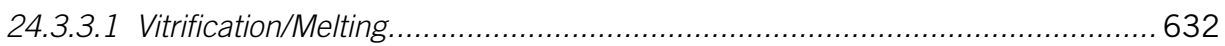

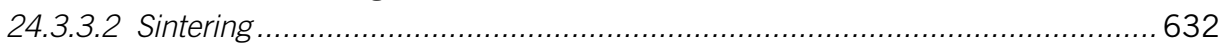

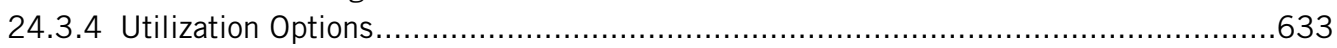

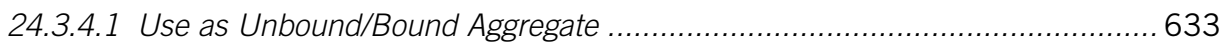

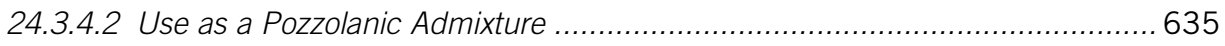

24.3.4.3 Use as Aggregate in Asphalt Mixtures................................................. 635

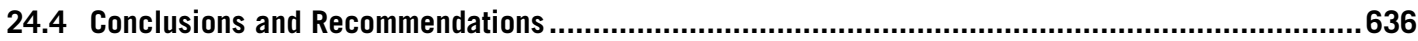

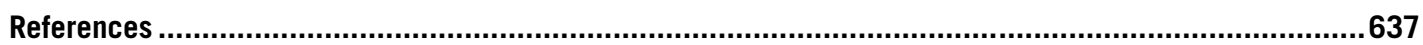




\section{1 INTRODUCTION}

Waste incineration based on mass-burn technology is currently the most commonly adopted method for the thermal treatment of municipal solid waste. Waste incineration further allows the recovery of energy from the waste, thereby providing significant savings with respect to environmental impacts (Fruergaard and Astrup, 2011; Vehlow, 2012, 2015). Modern municipal solid waste incinerators are typically equipped with effective flue gas-cleaning systems able to comply with the stringent air emission criteria employed in most countries (European Commission, 2006). As flue gas cleaning technologies improve, allowed air emissions can be assumed to be further lowered in the future. This renders the solid residues from the incineration processes the primary emission route for many contaminants out of the incineration plants. Consequently, the overall environmental profile of a waste incineration plant is to a large extent related to the quality and management of solid residues such as bottom ashes (BAs), fly ashes (FAs), and air pollution control (APC) residues. Of these residues, BAs are generated in the largest amounts $\left(150-300 \mathrm{~kg} \mathrm{t}^{-1}\right.$ of waste incinerated, with an average of $200 \mathrm{~kg} \mathrm{t}^{-1}$ ) and are at the same time the residues with technical properties most suited for use. From an environmental and management point of view, it is therefore essential to optimize BA processing to reduce landfilling of the residues and enhance utilization.

Over the past 2 decades, numerous studies have addressed aspects related to understanding the technical and environmental properties of incinerator BA as well as defining the suitable conditions for recycling. Investigations have focused on the leaching behavior (Meima and Comans, 1999, 1998; Meima et al., 2002; Polettini and Pomi, 2004; van Zomeren and Comans, 2004; Johnson et al., 1995; Dijkstra et al., 2006a; Freyssinet et al., 2002; Dijkstra et al., 2008), geochemical reactions (Meima and Comans, 1997; Eusden et al., 1999; Piantone et al., 2004; Astrup et al., 2006), weathering aspects (Meima and Comans, 1999, 1998; Polettini and Pomi, 2004; Freyssinet et al., 2002; Meima and Comans, 1997a; Piantone et al., 2004; Chimenos et al., 2000; Zevenbergen et al., 1996; Zevenbergen and Comans, 1994; Zevenbergen et al., 1998), upgrading and stabilization methods (Meima et al., 2002; Meima and Comans, 1998; Cheeseman et al., 2003; Bethanis, 2004; Arickx et al., 2006; van der Sloot et al., 2001; Crannell et al., 2000; Van Gerven et al., 2007), utilization options (Aberg et al., 2006; Onori et al., 2011a; Filipponi et al., 2003; Polettini et al., 2009, 2005a; Giampaolo et al., 2002; Pera et al., 1997; Pecqueur et al., 2001; Dabo et al., 2009; Olsson et al., 2006; Vegas et al., 2008; Cioffi et al., 2011; Triffault-Bouchet et al., 2005; Tang et al., 2015; Forteza et al., 2004) and pilot/full-scale experiences (Aberg et al., 2006; Dabo et al., 2009; De Windt et al., 2011; Hjelmar et al., 2007; François and Pierson, 2009). Internationally, the individual investigations to some extent reflect varying concerns and priorities in individual countries, but also provide an important knowledge base for improving BA management. Worldwide, current management of BA varies to a considerable extent: In some countries ashes are primarily landfilled without treatment and in other countries the ashes are treated extensively before use in construction works. The basic characteristics and problems related to BA and its processing are, however, generally similar across countries and regions. In this sense, huge potentials for building on existing knowledge and research experiences exist with a potential to provide improved solutions for BA management and use in the future.

The current chapter focuses on both state-of-the-art and innovative techniques for the treatment and reuse/recycling of incinerator BA. Based on a review of existing research, an outline of common 
characteristics of waste incineration BA as well as a discussion of important BA processing options with focus on effects on leaching are presented. The chapter further outlines important environmental aspects to be considered in relation to BA management and use.

\subsection{BOTTOM ASH CHARACTERISTICS}

This section provides an overview of BA characteristics, mineralogy and leaching behavior, and also includes identification of the constituents generally considered most critical from an environmental point of view.

\subsubsection{PHYSICAL CHARACTERISTICS}

Mass-burn incinerator BA typically consists of noncombustible or unburned materials collected at the outlet of the combustion chamber. BA is typically collected in a quenching tank with water but may also be collected dry. Water quenching of BA serves two main purposes: cooling of the material while preventing tertiary air from entering the combustion chamber. Compared with dry discharge, water quenching has the major drawbacks of causing the agglomeration of particles and the formation of glassy constituents along with a high water content of the ash discharged, which are both believed to affect the potential for metal recovery negatively (Meylan and Spoerri, 2014; Berkhout et al., 2011; Rem et al., 2004; De Vries et al., 2012) (see subsequent discussion for further details on practical implications).

For practical reasons, incinerators often combine BA with grate siftings (the fine materials passing through the grate) and in some cases also with the boiler ashes (the coarse fraction of particles carried over by the flue gas from the combustion chamber, which is collected in the heat recovery section). Although waste incinerators receive varying mixtures of waste input and the ash-handling options may differ, BAs often share common characteristics. Ash characteristics are affected considerably by the incinerator technology (eg, fluidized-bed incineration versus grate-fired incineration). Because gratefired mass-burn incineration is the most widespread and most robust technology for mixed municipal solid waste, only this technology is discussed in the current chapter.

Fresh, untreated BA contains all of the solids remaining after the incineration process (including in some cases grate siftings and boiler ashes, as mentioned earlier). The constituents of BA can be classified as noncombustible materials (waste glass, soil minerals, metals, and metal alloys) and melt products (glasses, silicate minerals, and oxide minerals) (Meima and Comans, 1997b). The mineral fraction of the BA is typically light to dark gray and is a granular material (although it may also contain large fused lumps). The particle size distribution is typical of well-graded materials and generally conforms with that of sandy gravel, with a content of 40-mm oversize particles commonly below 5\% by total mass (Tang et al., 2015; Forteza et al., 2004; Heinrichs et al., 2012; Izquierdo et al., 2011; Arm, 2004; Allegrini et al., 2014), as well as a low portion of fines $(<63 \mu \mathrm{m})$ (Izquierdo et al., 2011).

In addition to the mineral fraction (which usually accounts for 50-75\% of the total mass Berkhout et al., 2011; Šyc et al., 2015; Chimenos et al., 1999; Hu and Bakker, 2015; Sormunen and Rantsi, 2015), BA also contains a number of other components including ferrous metals (FeM) (iron and steel, $5-13 \%$ on average), nonferrous metals (NFeM) (mainly aluminum and stainless steel), and heavy 
nonferrous metals (HNFeM) (mainly $\mathrm{Cu}$ and $\mathrm{Zn}, 2-5 \%$ ), relict glass and ceramic particles (15-30\%), and unburned organic matter (0.2-5\%) (Berkhout et al., 2011; Heinrichs et al., 2012; Izquierdo et al., 2011; Šyc et al., 2015; Chimenos et al., 1999; Muchová and Rem, 2006; Holm et al., 2015). It has been reported in numerous studies that the content of such major components is largely variable concerning the grain size of the BA particles (Berkhout et al., 2011; Allegrini et al., 2014; Muchova et al., 2008), which also strongly affects the recovery potential of valuable fractions.

With regard to the recycling potential of BA, both the mineral and the metal fractions are potentially valuable. The former can be reused as an aggregate or be embedded in other materials such as cement, concrete or asphalt in a number of engineering applications, whereas the latter can be reused in the metal industry. Metals can be present in BA as metal scraps, either as metal particles physically adhering to the mineral fraction or as metallic species incorporated into the mineral structure. Obviously, the recovery of the different metal constituents requires increasingly larger efforts depending on the degree of their interaction with the mineral fraction.

\subsubsection{CHEMICAL CHARACTERISTICS}

\subsubsection{Inorganic Content}

The inorganic content of BA varies among incinerators, depending on the type of waste received, the incinerator technology, and the operating conditions of the incinerator (Hyks and Astrup, 2009). However, the contents of alkali metals, alkaline earth metals, and heavy metals typically vary within certain ranges regardless of the origin. Table 24.1 shows the typical elemental composition ranges as derived from various literature sources. In the table, the elemental constituents are grouped into the following categories: (1) major elements; (2) elements of potential environmental concern (ie, recognized as toxic or hazardous elements); (3) rare earth metals; (4) platinum group metals; and (5) other precious and critical elements. The last three groups of constituents have attracted considerable attention in the scientific literature (Allegrini et al., 2014, 2015; Muchová and Rem, 2006; Muchova et al., 2008; Funari et al., 2015; Morf et al., 2013) from the perspective of defining the overall resource recovery potential of incinerator BA.

Quantitatively, $\mathrm{Al}, \mathrm{Ca}, \mathrm{Cl}, \mathrm{Cu}, \mathrm{Fe}, \mathrm{K}, \mathrm{Mg}, \mathrm{Na}, \mathrm{P}, \mathrm{Pb}, \mathrm{S}, \mathrm{Si}$, and $\mathrm{Zn}$ are important inorganic constituents. As explained later in relation to ash mineralogy, in particular $\mathrm{Al}, \mathrm{Ba}, \mathrm{Ca}, \mathrm{K}, \mathrm{Mg}, \mathrm{S}$, and $\mathrm{Si}$ are important constituents of major solid phases controlling ash chemistry and $\mathrm{pH}$. On the other hand, it is generally acknowledged that the total metal content of the ash is not related to the potential environmental impact exerted by the material in their use or the disposal site. Metals are typically considered of concern once they are released into the environment by leaching (see later discussion regarding the leaching properties).

As for the metal recovery potential from BA, the total economic value of the main recoverable metals estimated on the basis of their respective concentration ranges (Table 24.1); market prices are reported in Fig. 24.1. The reported values indicate that, as observed in previous investigations (Allegrini et al., 2014; Funari et al., 2015; Morf et al., 2013), the concentration of most rare earth elements as well as platinum group and other precious metals, although often of the same order of magnitude as their content in the upper continental crust, is generally much lower than that typical of concentrated ores and therefore is too low to justify any potential recovery option. Also, the real economic value of BA would be affected by the actual recovery yield, selectivity, and degree of 
Table 24.1 Observed Ranges for Elemental Content of Bottom Ash From Different Literature Sources (Allegrini et al., 2014; Funari et al., 2015; Morf et al., 2013; Chandler et al., 1997; Sabbas et al., 2003; Bayuseno and Schmahl, 2010; Chung et al., 2007; Fujimori et al., 2004, 2005; Jung and Osako, 2007; Kida et al., 1996; Zhang et al., 2001; Zhao et al., 2008)

\begin{tabular}{|c|c|}
\hline Element & $\begin{array}{l}\text { Concentration Range (mg/kg) } \\
\text { (Minimum to Maximum) }\end{array}$ \\
\hline \multicolumn{2}{|c|}{ Major elements } \\
\hline $\mathrm{Al}$ & $14,000-79,000$ \\
\hline $\mathrm{Ca}$ & $8600-170,000$ \\
\hline $\mathrm{Fe}$ & $3100-150,000$ \\
\hline $\mathrm{K}$ & $660-16,000$ \\
\hline $\mathrm{Mg}$ & $240-26,000$ \\
\hline Mn & $7.7-3200$ \\
\hline $\mathrm{Na}$ & $2200-42,000$ \\
\hline $\mathrm{P}$ & $440-10,500$ \\
\hline $\mathrm{Si}$ & $4300-308,000$ \\
\hline
\end{tabular}

Elements of potential environmental concern

\begin{tabular}{|l|l|}
\hline $\mathrm{As}$ & $0.12-190$ \\
$\mathrm{Ba}$ & $69-5700$ \\
$\mathrm{Cd}$ & $0.3-70$ \\
$\mathrm{Cu}$ & $190-25,000$ \\
$\mathrm{Cr}$ & $20-3400$ \\
$\mathrm{Mo}$ & $2.5-280$ \\
$\mathrm{Ni}$ & $7-4300$ \\
$\mathrm{~Pb}$ & $75-14,000$ \\
$\mathrm{Se}$ & $0.05-10$ \\
$\mathrm{Sn}$ & $2-470$ \\
$\mathrm{Tl}$ & $0.0077-0.23$ \\
$\mathrm{~V}$ & $16-120$ \\
$\mathrm{Zn}$ & $10-20,000$ \\
\hline $\mathrm{Rare}$ earth elements & \\
\hline $\mathrm{Sc}$ & $1.3-22$ \\
$\mathrm{La}$ & $2-30$ \\
$\mathrm{Ce}$ & $11-51$ \\
$\mathrm{Pr}$ & $1.1-10$ \\
$\mathrm{Nd}$ & $4.0-37$ \\
$\mathrm{Sm}$ & $0.93-5$ \\
$\mathrm{Eu}$ & $0.25-2.6$ \\
$\mathrm{Gd}$ & $0.88-5$ \\
\hline
\end{tabular}




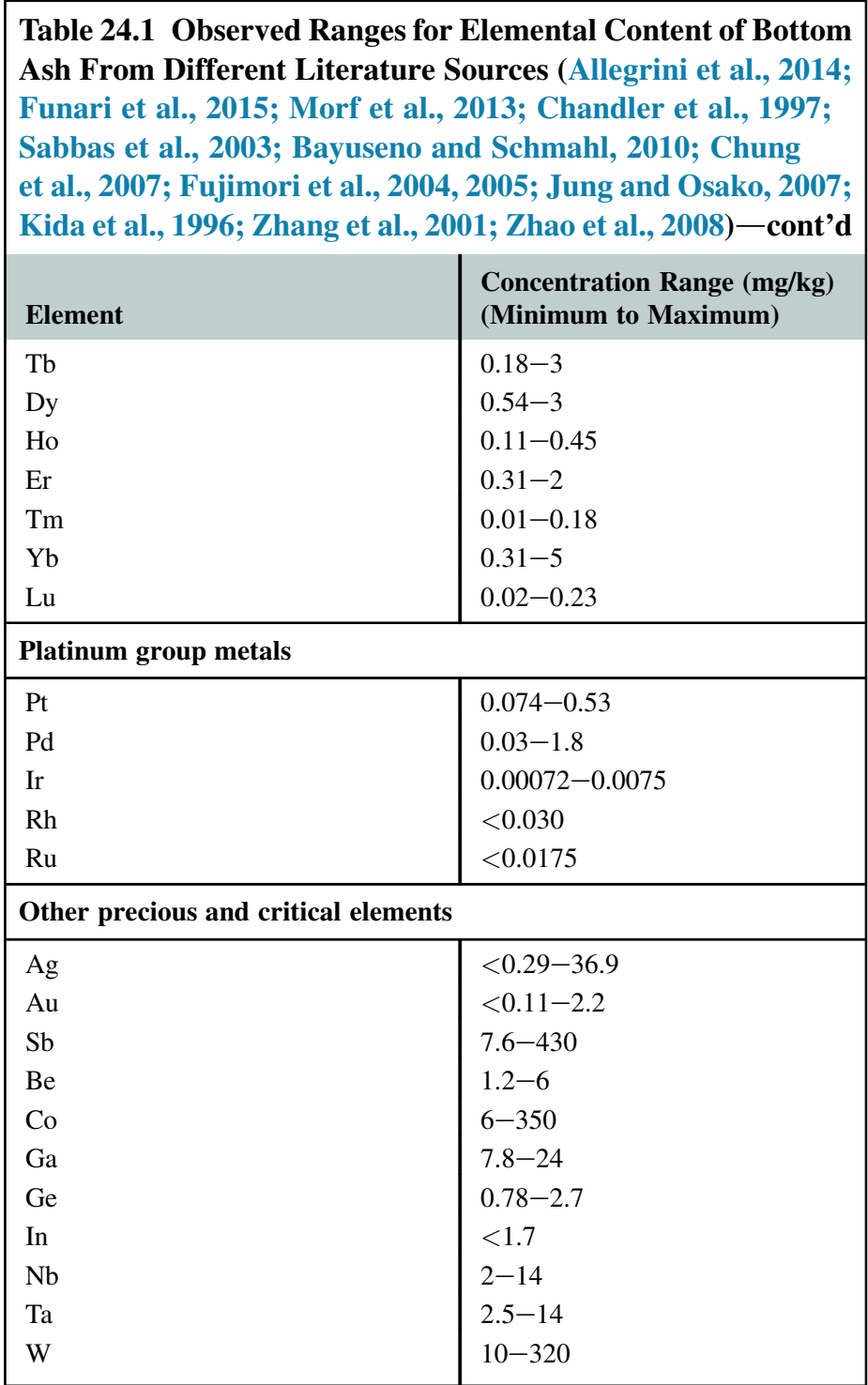

purity of the extracted metals that can be attained through hydrometallurgical extraction processes (Allegrini et al., 2014). The data in Fig. 24.1 show that, as similarly pointed out by Morf et al. (2013), most (about 85\%) of the total economic value of BA is in fact associated with few elements, including $\mathrm{Al}, \mathrm{Si}, \mathrm{Cu}, \mathrm{Cr}, \mathrm{Ni}$, and $\mathrm{Au}$ (assuming for this metal the upper value for the concentration range in Table 24.1). This provides some useful indications about the fact that there is little economic 


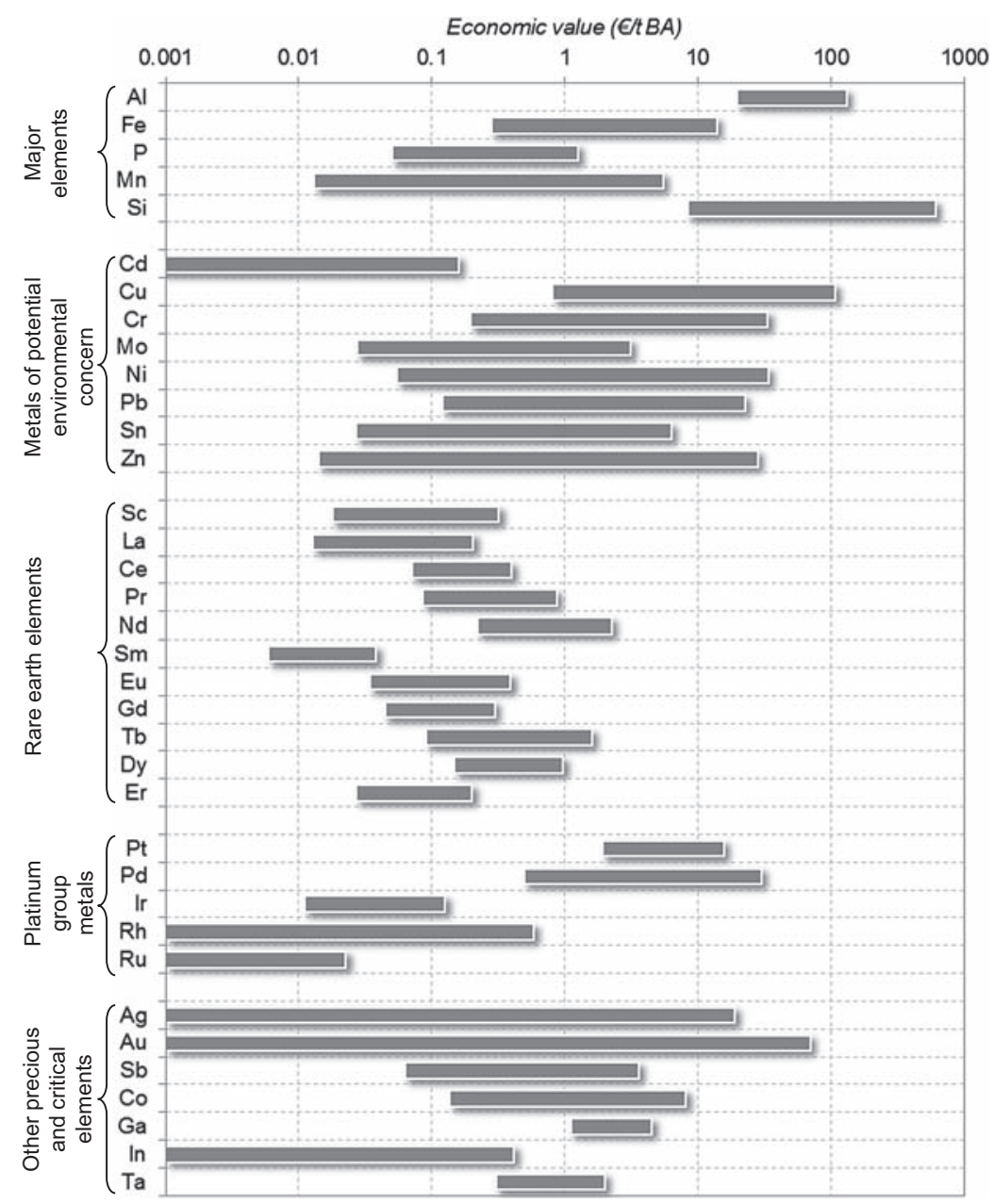

FIGURE 24.1

Estimated total economic value of metals in BA.

incentive to recover other metals than the ones mentioned, unless the recovery methods can be applied at very low additional costs.

\subsubsection{Organic Content}

Organic carbon is a relevant constituent of BA, because it has been extensively reported to have the capability, even at low concentrations, of affecting the leaching behavior of a number of inorganic components. According to van Zomeren and Comans (van Zomeren and Comans, 2009), carbon may be present in BA in different forms (Fig. 24.2). Specifically, total organic carbon is speciated between 


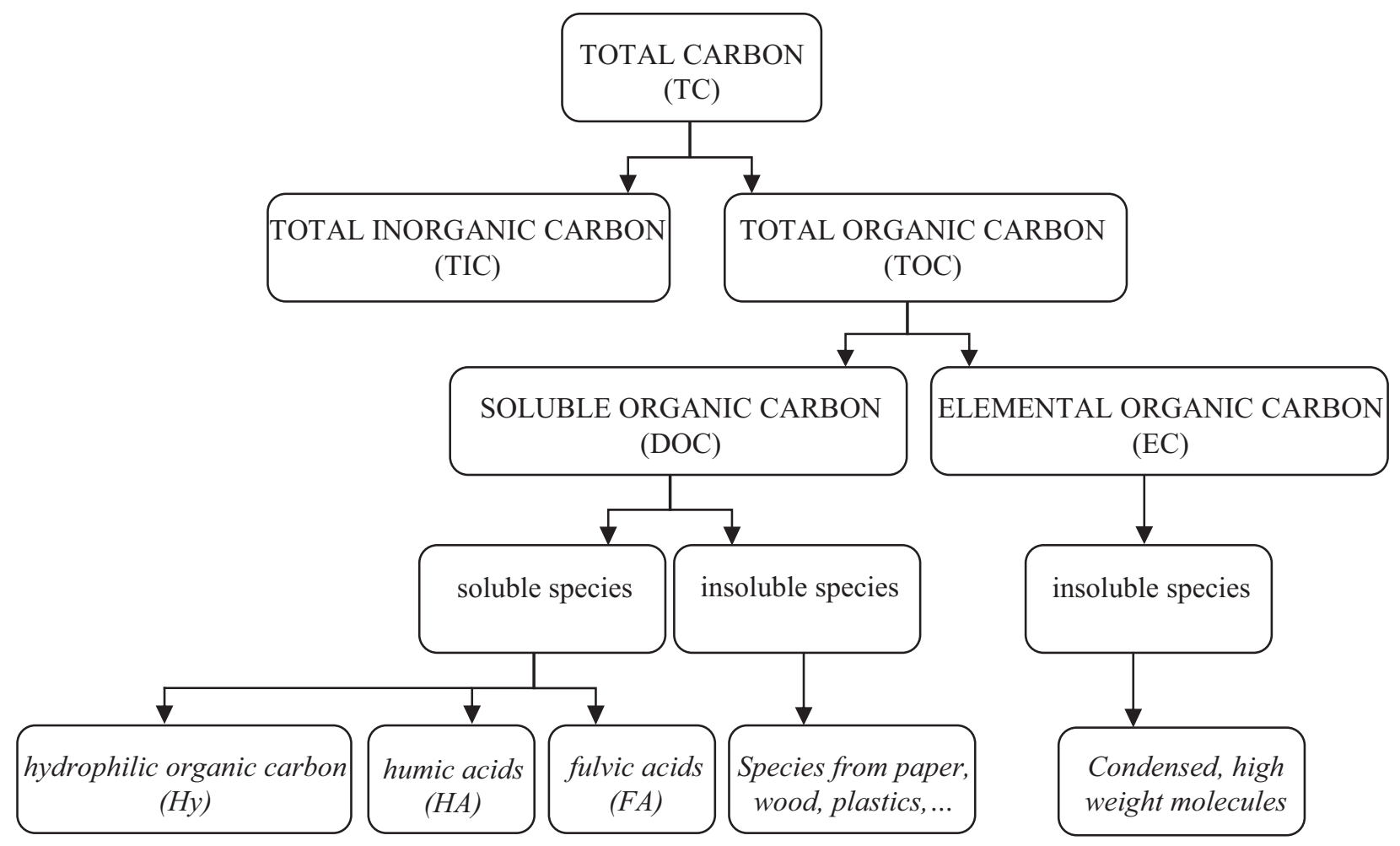

FIGURE 24.2

Carbon speciation in MSWI BA.

Adapted from van Zomeren and Comans (2009). 
elemental and organic carbon species (van Zomeren and Comans, 2009; Rocca et al., 2013), which exhibit different properties in terms of water solubility and stability. Owing to its chemical structure, elemental carbon has an extremely low solubility and high stability, and may contribute to adsorption between organic micropollutants and particle surfaces (van Zomeren and Comans, 2009; Cornelissen et al., 2005). Conversely, organic carbon includes soluble, and less biologically stable, organic compounds (humic and fulvic acids, along with the so-called "hydrophilic organic compounds" such as carbohydrates) as well as an insoluble fraction, which cannot be extracted even under acidic or basic conditions. The portion of humic and fulvic acids, along with the hydrophilic organic compounds, that can be leached out from the solid matrix is found in solution in the form of dissolved organic carbon (DOC), which thus represents an aggregate parameter. Several studies have pointed to the role of DOC in the enhanced leaching of heavy metals from municipal solid waste incineration (MSWI) BA (van Zomeren and Comans, 2004; Chandler et al., 1997; Meima et al., 1999). It has been demonstrated that humic and fulvic acids are present in incinerator BA (van Zomeren and Comans, 2004; Dijkstra et al., 2008; Arickx et al., 2007) and possess a high complexing capacity for heavy metals, including, eg, $\mathrm{Cu}$ above all (Arickx et al., 2007, 2010; Milne et al., 2003; Yao et al., 2010; Hyks et al., 2009; Olsson et al., 2007).

To highlight the short- and long-term behavior of BA, the potential microbial activity also should be taken into account. By measuring the biodegradable organic carbon (BOC) through respiration tests, some researchers (Rendek et al., 2006a) found that this was linearly correlated with DOC, and suggested that a link between leachable and biodegradable organic carbon exists, although evidence of correlation between total organic carbon (TOC) and BOC or DOC was not evidenced.

\subsubsection{Mineralogy and Geochemical Characteristics}

The mineralogical composition of BA is well established as being capable of dictating the chemical and leaching properties of the material. BA mineralogy is also known to change with time as a result of the chemical and mineralogical transformations occurring during weathering, which comprise numerous interrelated processes such as hydrolysis, hydration, dissolution/precipitation, carbonation, complexation with organic and inorganic ligands, oxidation/reduction, surface complexation, surface (co)precipitation, sorption, ion exchange, formation of solid solutions and others (for further details see, eg, Sabbas et al. (2003)). As a result of mineralogical alterations, the basic properties of $\mathrm{BA}$, including $\mathrm{pH}$ and acid neutralization capacity, are also expected to change, in turn affecting leaching.

Because of the importance of these issues, a number of studies have focused on the mineralogical characteristics of incinerator BA (Eusden et al., 1999; Kirby and Rimstidt, 1993), in some cases also investigating the influence that aging may exert on them (Piantone et al., 2004; Zevenbergen et al., 1996, 1998; Bayuseno and Schmahl, 2010; Wei et al., 2011). From a mineralogical point of view, incinerator BA is recognized to be a multicomponent material with a partially amorphous character. The commonly detected components have different characteristics in terms of chemical composition and mineralogical association, and typically include a low-density slag or melt phase which often also incorporates metal impurities, as well as a vitreous phase with variable quantities of crystals and glassy material. A rough distinction is often made between refractory components (including high-melting point solids contained in the original material, which remain unchanged or only partially melted upon combustion) and newly formed glassy and crystalline products. As reported in Table 24.2, silicates (quartz), aluminosilicates of $\mathrm{Ca}$ and $\mathrm{Na}$ (melilite minerals such as gehlenite and akermanite, feldspars, 


\begin{tabular}{|c|c|c|c|c|}
\hline \multirow[b]{2}{*}{ Mineral } & \multirow[b]{2}{*}{ Formula } & \multicolumn{2}{|c|}{$\begin{array}{l}\text { Presence in Bottom } \\
\text { Ash }\end{array}$} & \multirow[b]{2}{*}{ References } \\
\hline & & Fresh & Weathered & \\
\hline \multicolumn{5}{|c|}{ Refractory components } \\
\hline $\begin{array}{l}\text { Feldspar minerals } \\
\text { Biotite } \\
\text { Olivine } \\
\text { Pyroxene }\end{array}$ & $\begin{array}{l}\mathrm{SiO}_{2} \\
(\mathrm{~K}, \mathrm{Ca}, \mathrm{Na})\left(\mathrm{Al}, \mathrm{Si}_{4} \mathrm{O}_{8}\right. \\
\mathrm{K}(\mathrm{Mg}, \mathrm{Fe})_{3} \mathrm{AlSi}_{3} \mathrm{O}_{10} \mathrm{O}_{22}(\mathrm{OH})_{2} \\
(\mathrm{Mg}, \mathrm{Fe})_{2} \mathrm{SiO}_{4} \\
\mathrm{Ca}(\mathrm{Mg}, \mathrm{Fe}) \mathrm{Si}_{2} \mathrm{O}_{6}\end{array}$ & $\begin{array}{r}\times \\
\times \\
\times \\
\times\end{array}$ & $\times$ & $\begin{array}{l}\text { Eusden et al. (1999), Zevenbergen et al. (1998), Kirby and } \\
\text { Rimstidt (1993), Bayuseno and Schmahl (2010), Baciocchi } \\
\text { et al. (2010) } \\
\text { Eusden et al. (1999) } \\
\text { Eusden et al. (1999) } \\
\text { Eusden et al. (1999), Bayuseno and Schmahl (2010) } \\
\text { Eusden et al. (1999), Bayuseno and Schmahl (2010) }\end{array}$ \\
\hline \multicolumn{5}{|c|}{ Newly formed products } \\
\hline $\begin{array}{l}\text { Melilite-group } \\
\text { minerals: }\end{array}$ & & & & \\
\hline $\begin{array}{l}\text { Ghelenite } \\
\text { Akermanite } \\
\text { Spinel-group } \\
\text { minerals: }\end{array}$ & $\begin{array}{l}\mathrm{Ca}_{2} \mathrm{Al}_{2} \mathrm{SiO}_{7} \\
\mathrm{Ca}_{2}(\mathrm{Mg}, \mathrm{Fe}) \mathrm{Si}_{2} \mathrm{O}_{7}\end{array}$ & $x$ & $x$ & $\begin{array}{l}\text { Eusden et al. (1999), Zevenbergen et al. (1998), Kirby and } \\
\text { Rimstidt (1993), Wei et al. (2011), Baciocchi et al. (2010) }\end{array}$ \\
\hline $\begin{array}{l}\text { Magnetite } \\
\text { Hercynite }\end{array}$ & $\begin{array}{l}\mathrm{Fe}_{3} \mathrm{O}_{4} \\
\mathrm{FeAl}_{2} \mathrm{O}_{4}\end{array}$ & $x$ & $x$ & $\begin{array}{l}\text { Eusden et al. (1999), Zevenbergen et al. (1998), Bayuseno and } \\
\text { Schmahl (2010), Wei et al. (2011) }\end{array}$ \\
\hline Hematite & $\mathrm{Fe}_{2} \mathrm{O}_{3}$ & $x$ & $x$ & $\begin{array}{l}\text { Piantone et al. (2004), Zevenbergen et al. (1998), Kirby and } \\
\text { Rimstidt (1993), Baciocchi et al. (2010) }\end{array}$ \\
\hline Feldspar minerals & $(\mathrm{Ca}, \mathrm{Na})(\mathrm{Al}, \mathrm{Si})_{4} \mathrm{O}_{8}$ & $x$ & & Eusden et al. (1999) \\
\hline
\end{tabular}




\begin{tabular}{|c|c|c|c|c|}
\hline Wollastonite & $\mathrm{CaSiO}_{3}$ & $x$ & & Eusden et al. (1999), Wei et al. (2011) \\
\hline Chromite & $\mathrm{FeCr}_{2} \mathrm{O}_{4}$ & $x$ & & Eusden et al. (1999) \\
\hline Lime & $\mathrm{CaO}$ & $x$ & & Eusden et al. (1999) \\
\hline Portlandite & $\mathrm{Ca}(\mathrm{OH})_{2}$ & $\times$ & & Wei et al. (2011), Baciocchi et al. (2010) \\
\hline $\begin{array}{l}\text { Ca carbonates: } \\
\text { calcite, vaterite }\end{array}$ & $\mathrm{CaCO}_{3}$ & $x$ & $x$ & $\begin{array}{l}\text { Piantone et al. (2004), Zevenbergen et al. (1998), Kirby and } \\
\text { Rimstidt (1993), Baciocchi et al. (2010) }\end{array}$ \\
\hline Sulfates: & & & & \\
\hline $\begin{array}{l}\text { Anhydrite } \\
\text { Gypsum } \\
\text { Aluminocopiapite }\end{array}$ & $\begin{array}{l}\mathrm{CaSO}_{4} \\
\mathrm{CaSO}_{4} \cdot 2 \mathrm{H}_{2} \mathrm{O} \\
\mathrm{Al}_{2 / 3} \mathrm{Fe}_{4}(\mathrm{OH})_{2}\left(\mathrm{SO}_{4}\right)_{6} \cdot 20 \mathrm{H}_{2} \mathrm{O}\end{array}$ & $x$ & $x$ & $\begin{array}{l}\text { Polettini and Pomi (2004), Piantone et al. (2004), Zevenbergen } \\
\text { et al. (1998) }\end{array}$ \\
\hline Ettringite & $\mathrm{Ca}_{6} \mathrm{Al}_{2}\left(\mathrm{SO}_{4}\right)_{3}(\mathrm{OH})_{12} \cdot 26 \mathrm{H}_{2} \mathrm{O}$ & $x$ & $x$ & $\begin{array}{l}\text { Polettini and Pomi (2004), Piantone et al. (2004), Zevenbergen } \\
\text { et al. (1998), Bayuseno and Schmahl (2010) }\end{array}$ \\
\hline $\begin{array}{l}\text { Weddellite } \\
\text { Hydroxides: }\end{array}$ & $\mathrm{CaC}_{2} \mathrm{O}_{4} \cdot 2 \mathrm{H}_{2} \mathrm{O}$ & $x$ & & Piantone et al. (2004) \\
\hline $\begin{array}{l}\text { Goethite } \\
\text { Gibbsite }\end{array}$ & $\begin{array}{l}\mathrm{FeOOH} \\
\mathrm{AlOOH}\end{array}$ & $x$ & $x$ & Piantone et al. (2004) \\
\hline $\begin{array}{l}\text { Ca silicate } \\
\text { hydrates }\end{array}$ & C-S-H-type phases & & $x$ & Piantone et al. (2004), Bayuseno and Schmahl (2010) \\
\hline Zeolites & & & $x$ & Piantone et al. (2004), Bayuseno and Schmahl (2010) \\
\hline $\begin{array}{l}\text { Clay-group } \\
\text { minerals }\end{array}$ & & & $x$ & $\begin{array}{l}\text { Piantone et al. (2004), Zevenbergen et al. (1998), Bayuseno and } \\
\text { Schmahl (2010) }\end{array}$ \\
\hline Corundum & $\mathrm{Al}_{2} \mathrm{O}_{3}$ & $x$ & $x$ & Polettini and Pomi (2004), Bayuseno and Schmahl (2010) \\
\hline $\begin{array}{l}\text { Muscovite-group } \\
\text { minerals }\end{array}$ & & $x$ & & Bayuseno and Schmahl (2010) \\
\hline
\end{tabular}


pyroxene minerals, olivine, pseudowollastonite, alite, and belite), metal oxides (magnetite and corundum), hydroxides (portlandite), sulfates (anhydrite, gypsum, and ettringite), carbonates (calcite and siderite), as well as metallic inclusions encapsulated in the melt phase are recognized as the most common phases in BA.

It has also been reported (Zevenbergen and Comans, 1994; Zevenbergen et al., 1998; Bayuseno and Schmahl, 2010; Wei et al., 2011) that weathering causes mineralogical alterations on different time scales. At the initial stages of the process, changes in mineralogy are mainly related to the alteration, at a relatively fast rate, of Ca-rich solids in the strongly alkaline environment which is established, with consequent precipitation of carbonate minerals (see subsequent discussion for additional details) and $\mathrm{Al}$ (oxy)hydroxides such as ferrihydrite and gibbsite, as well as dissolution of ettringite with gypsum formation. At later stages of the process, mineralogical changes are instead dominated by slow alteration of the silicate-based glassy components, which are comparatively more resistant to the external environmental conditions. The alteration of the glassy phase is also believed to result in mainly new amorphous or poorly crystalline phases, which are formed as $\mathrm{Ca}, \mathrm{Al}$, and other elements are released during the dissolution reactions. Reported products of glass weathering include hydrated silicates, aluminates, and sulfates (hydrocalumite, C-S-H-type phases, gypsum, clay minerals, and zeolites).

\subsubsection{Leaching Behavior}

Risks associated with the transfer of potentially hazardous components from BA to groundwater, surface water, and soil are recognized to be determined by their leaching potential rather than by their total content in the solid material (Dijkstra et al., 2006a). As a consequence, comprehensive information on the leaching behavior of BA is of paramount importance to evaluate the potential environmental impacts of the material correctly under the intended use scenarios or during final disposal. At the European level, it is commonly acknowledged that the estimation of contaminant release from waste materials should be based on the results of multiple standardized leaching tests, the objective of which is to address different aspects of contaminant release under a wide range of environmental conditions. To this aim, specific standard leaching procedures have been developed in the different countries; in Europe, testing procedures have been defined by the standardization committees CEN/TC 292: "Characterisation of waste" and CEN/TC 351: "Construction products: Assessment of the release of dangerous substances." Of course, the amount of information required to estimate the extent of contaminant leaching from the waste matrix is a function of the target one wishes to attain through a leaching test (characterization testing with an in-depth evaluation of the underlying mechanisms governing leaching, compliance testing to verify whether a waste material is suitable for certain purposes, and quality control testing to evaluate, eg, the variability in the waste characteristics).

It is well established that no correlation exists between the leaching of elements (except for highly soluble salts) from predominantly inorganic waste materials such as incinerator BA and their respective total content in the ash (Hyks and Astrup, 2009; Saveyn et al., 2014). Leaching has also been found to be poorly dependent on both the incinerator operating conditions and the composition of the waste input to the incinerator (Hyks and Astrup, 2009). Thus, with the exception of elements associated with highly soluble salts such as $\mathrm{Na}, \mathrm{K}$, and $\mathrm{Cl}$, for which leaching is determined by their availability and is therefore directly related to their total content in the material (Hjelmar, 1996), the leaching behavior of major and trace elements in BA is largely dominated by the 
dissolution/precipitation reactions of common mineral phases (Meima and Comans, 1997, 1999; Meima et al., 1999) as well as (particularly for weathered BA) by the interaction of elements with reactive surfaces (mainly $\mathrm{Fe}$ and $\mathrm{Al}$ [hydr]oxides) and complexing components (organic matter) (Meima and Comans, 1998; Dijkstra et al., 2006b, 2008; Meima and Comans, 1998; Dijkstra et al., 2002). A brief overview of the main geochemical processes governing the leaching of individual elements/components from the BA matrix is provided in Table 24.3.

Several countries have developed criteria or regulations to define the conditions for reuse of waste materials (including incinerator BA) in different applications. In some cases, both unrestricted and restricted reuse scenarios are identified on the basis of both the total content of contaminants in the ash and their leaching behavior. Because the leaching test procedures required to evaluate the suitability of waste materials for use generally differ among countries, the limit values are likewise different depending on the specific evaluation approach adopted (Table 24.4). However, irrespective of the individual criteria adopted, there is some general agreement that, among the contaminants of potential environmental concern, $\mathrm{Cu}, \mathrm{Mo}, \mathrm{Sb}, \mathrm{Cl}$, and $\mathrm{SO}_{4}$ may represent critical substances with respect to the

\section{Table 24.3 Overview of Geochemical Processes Reported to Control Leaching of Major and Minor Elements or Components From Quenched Noncarbonated Municipal Solid Waste Incineration Bottom Ash (Meima and Comans, 1999, 1998; Dijkstra et al., 2006a; Dijkstra et al., 2008; Meima and Comans, 1997a, 1998; Meima et al., 1999; Hjelmar, 1996; Dijkstra et al., 2002; Cornelis et al., 2006, 2008, 2012)}

\begin{tabular}{l|l} 
Element \\
$\mathrm{Ca}, \mathrm{SO}_{4}, \mathrm{CO}_{3}$ \\
$\mathrm{Al}$ \\
$\mathrm{Fe}$ \\
$\mathrm{Mg}$ \\
$\mathrm{Si}$ \\
$\mathrm{Na}, \mathrm{K}, \mathrm{Cl}$ \\
$\mathrm{Mo}$ \\
$\mathrm{Sb}$ \\
$\mathrm{Cu}$ \\
$\mathrm{Pb}$ \\
$\mathrm{Zn}$ \\
$\mathrm{Cd}$ \\
$\mathrm{Others}(\mathrm{Mn}, \mathrm{Ba}, \mathrm{V})$
\end{tabular}

\section{Controlling Mechanism}

Solubility control by ettringite and gypsum/anhydrite

Solubility control by calcite/monohydrocalcite

Solubility control by gibbsite, amorphous $\mathrm{Al}(\mathrm{OH})_{3}$ or amorphous $\mathrm{Al}$ silicates

Solubility control by ferrihydrite

Solubility control by brucite or magnesite

Solubility control by wairakite, amorphous $\mathrm{SiO}_{2}$ or amorphous Ca-Al-silicates

Solubility control by availability of corresponding salts

Solubility control by powellite

Solubility control by $\mathrm{Ca}$ antimonates

Incorporation into ettringite

Organic complexation by fulvic acids.

Solubility control by tenorite/ $\mathrm{Cu}(\mathrm{OH})_{2}$

Sorption control by amorphous $\mathrm{Al}$ minerals

Solubility control by cerussite or $\mathrm{Pb}(\mathrm{OH})_{2}$.

Sorption control by amorphous Al minerals.

Organic complexation

Solubility control by zincite, $\mathrm{Zn}(\mathrm{OH})_{2}$ or $\mathrm{ZnSiO}_{3}$.

Sorption control by amorphous $\mathrm{Al}$ minerals

Solubility control by otavite.

Sorption by amorphous Al silicates

Solubility control by $\mathrm{MnO}(\mathrm{OH})$, barite and $\mathrm{Pb}_{2} \mathrm{~V}_{2} \mathrm{O}_{7}$ 


\begin{tabular}{|c|c|c|}
\hline Country & Applied Criteria & $\begin{array}{l}\text { Leaching Test } \\
\text { Procedure Required }\end{array}$ \\
\hline Austria & Total content + leaching & EN 12457-4 \\
\hline Belgium (Flanders) & Total content + leaching & CEN/TS 14405 \\
\hline Czech Republic & Total content + leaching & EN 12457-4 \\
\hline Denmark & Total content + leaching & EN 12457-1 \\
\hline Finland & Total content + leaching & $\begin{array}{l}\text { EN 12457-3 } \\
\text { CEN/TS } 14405\end{array}$ \\
\hline France & Total content + leaching & $\begin{array}{l}\text { EN } 12457-2 \text { and } 4 \\
\text { CEN/TS } 14405\end{array}$ \\
\hline Germany & Total content + leaching & $\begin{array}{l}\text { EN 12457-2 } \\
\text { DIN } 19528\end{array}$ \\
\hline Italy & Leaching & EN 12457-2 \\
\hline The Netherlands & Total content + leaching & CEN/TS 14405 \\
\hline Spain (selected regions) & Leaching & $\begin{array}{l}\text { EN 12457-4 } \\
\text { DIN 38414-S4 }\end{array}$ \\
\hline Sweden & Total content + leaching & CEN/TS 14405 \\
\hline
\end{tabular}

potential environmental impacts from BA use (Sormunen and Rantsi, 2015; Saveyn et al., 2014; De Wijs and Cleven, 2008). For this reason, if BA is intended to be reused in civil engineering applications, dedicated efforts should be devoted, eg, through appropriate BA pretreatment, to improve the environmental profile of the material with major regard to those specific contaminants. The specific effects of the individual treatment options on the leaching behavior of critical contaminants are outlined in the subsequent sections. As will be noted later in the chapter, the various treatment processes available act differently on modifying the leaching of the various potentially harmful components; therefore, careful selection of the type of treatment applied should be conducted with a view to meeting the standards required for use.

\subsection{BOTTOM ASH PROCESSING}

The processing methods that have been proposed and are in some cases routinely applied to incinerator BA have two main purposes: the separation of valuable fractions (basically, the mineral and metal fractions) to be reused in different applications and improvement in their technical and environmental behavior to meet the requirements set by technical standards for the use and regulatory thresholds for the reduction of potential environmental impacts.

The following provides an overview of the most important processing and treatment techniques applied to BA. The techniques are discussed with respect to their recycling potential as well as their potential effects on the leaching behavior of the material. 


\subsubsection{EXTRACTION AND SEPARATION}

\subsubsection{Integrated Scrubbing}

The common use of quenching tanks for BA cooling provides an opportunity to separate a large portion of the readily soluble components (mainly chloride and, to a lesser extent, sulfate salts) through integrated scrubbing. The relatively high temperatures (about $70^{\circ} \mathrm{C}$ ) in the quenching tank contribute to create the conditions for a high rate of dissolution. If relatively clean surplus water is added and/or the contact time between water and the incineration residues is increased, a reduction of more than $50 \%$ in readily soluble salts can be achieved (Zwahr, 2004). However, regarding the leaching of metals, integrated scrubbing is not expected to result in a significant improvement with a view to use, because as mentioned earlier, most metal contaminants display solubility- rather than availabilitycontrolled leaching.

\subsubsection{Mechanical Separation}

Mechanical separation of BA components has become a routine practice in several incineration plants, especially in northern Europe, and together with aging represents the most widely adopted treatment method of incineration BA. As outlined in the previous sections, BA is increasingly recognized as a source for high-value materials, which justifies the considerable economic drive to enhanced recovery of BA fractions. It has been shown (Berkhout et al., 2011) that the value of NFeM recovered from BA alone is sufficient to cover the costs of the entire treatment sequence for the production of the recycled mineral fraction. The environmental benefits of recycling of BA fractions are obviously associated with the reduced consumption of natural resources and avoided emissions from the primary industrial production processes. For instance, the production of secondary $\mathrm{Al}$ from recycled metal scraps requires approximately $6 \%$ of the energy demand of $\mathrm{Al}$ production from virgin materials, which amounts to about $45 \mathrm{kWh} \mathrm{kg}^{-1}$ of metal (Hu and Rem, 2009). Lifecycle assessment (LCA) studies of BA recovery showed that the related savings in greenhouse gas emissions are on the order of $100-400 \mathrm{~kg} \mathrm{CO}_{2} \mathrm{t}^{-1}$ BA processed, depending on the assumptions adopted and the specific conditions considered (Allegrini et al., 2015; Boesch et al., 2014), with a major contribution of $\mathrm{Al}(>50 \%)$ and $\mathrm{Fe}(35 \%)$ recovery. However, potential toxic impacts of BA recycling may be critical, mainly owing to Fe scrap recovery (Allegrini et al., 2015), although it was also observed that this may be the result of an overestimation of contaminant release by the adopted inventory of process emissions.

Enhanced recovery of metals from BA is also expected to result in benefits in terms of the technical performance of the separated mineral fraction for use as an aggregate or mineral addition in cement, concrete or asphalt mixtures in construction applications, because diverting metallic constituents may avoid documented detrimental effects in the usage site (Allegrini et al., 2015), including the oxidation of metallic $\mathrm{Al}$ with associated $\mathrm{H}_{2}$ production and expansion or cracking phenomena in concrete products caused by the formation of ettringite.

Separation of the metal and mineral fractions of BA is usually accomplished through an often complex treatment sequence which combines traditional processing and classification units (sieve separation, crushing, impact crushing, attrition liberation, magnetic separation, eddy current separation, air classification, hydraulic separation, and aging) with more advanced classification techniques (optical separation, magnetic density separation, X-ray classification, and electrodynamic fragmentation) (Berkhout et al., 2011; Holm et al., 2015). Most commonly, dry processing is applied (Holm et al., 2015; Hu et al., 2009), although wet-processing techniques have been proposed 
(Berkhout et al., 2011; Hu and Bakker, 2015; Muchová and Rem, 2006; Muchova et al., 2008; Hu and Rem, 2009) to overcome the negative effects of the high moisture content in the ash that is thought to impair the recovery of NFeM and improve the separation of the light organic fraction which tends to adhere to the metal particles. Application of combined dry and wet separation techniques has led to full-scale implementations, particularly in The Netherlands (e.g. Keulen et al., 2016).

The need to combine multiple processing units in BA treatment plants stems from the fact that although recovery yields for ferrous scraps in excess of $80 \%$ are commonly achieved (Meylan and Spoerri, 2014; Allegrini et al., 2014; Muchová and Rem, 2006), efficient recovery of NFeM is considerably more sensitive to the feed material characteristics, requiring in particular an accurate control of the grain size range of the material streams fed to the metal separation units (European Commission, 2006; Heinrichs et al., 2012; Allegrini et al., 2014; Holm et al., 2015; Hu and Rem, 2009; Hu et al., 2009). In particular, the finer fractions are known to contribute significantly to the inventory of HNFeM in BA (Allegrini et al., 2014; Hu and Bakker, 2015; Muchová and Rem, 2006; Hu et al., 2009; Biganzoli et al., 2013; Muchova, 2010; Grosso et al., 2011). To this aim, in modern BA separation plants, multiple size fractions are usually processed in parallel (Rem et al., 2004; De Vries et al., 2012; Heinrichs et al., 2012; Allegrini et al., 2014; Šyc et al., 2015; Hu and Bakker, 2015; Holm et al., 2015; Muchova et al., 2008; Hu and Rem, 2009; Hu et al., 2009; Biganzoli et al., 2013; Muchova, 2010). It has been suggested (Heinrichs et al., 2012) that an optimized feed to eddy-current separation should have a ratio of 3 between the upper and lower diameters of the particle size range.

An overview of the treatment layout of different BA processing plants aimed at separating various fractions (typically, mineral fraction, ferrous scraps, and NFeM, either combined or individually), with details (when available) on the related recovery rates, is provided in Table 24.5.

\subsubsection{Extraction With Water, Acids, and Chelating Agents}

Slurry-phase extraction of metal contaminants from BA using various extracting agents has been proposed as a means to improve the leaching behavior of the mineral fraction in view of its use as an aggregate material. Washing with water is the simplest process that can be applied to remove soluble constituents from BA. The L/S ratio and residence time in the BA quenching tank are such that the thermodynamic equilibrium of the dissolution processes is seldom attained. Thus, after quenching BA will still contain residual soluble components which can be further extracted through a water washing treatment. Because of the alkaline nature of BA, the $\mathrm{pH}$ of fresh $\mathrm{BA}-$ water suspensions is typically in the range 9.5-12, which corresponds to the solubility minimum for most metal species. For this reason and through the fact that the leaching of most metals is solubility-controlled (leaching is determined by the solubility of certain minerals present), the efficiency of trace metal removal from BA through water washing is typically relatively low. Hence, this and the treatment is mainly applied to remove major components that are soluble, such as chloride, $\mathrm{Na}$, and sulfate. However, the less soluble sulfate minerals may not dissolve completely upon water washing, which makes the treatment generally unsuitable to improve the leaching characteristics of BA at the level required by regulation for reuse.

Enhanced sulfate solubilization yields have been reported using $\mathrm{NaHCO}_{3}$ or $\mathrm{CO}_{2}$ in the washing solution, owing to the precipitation of $\mathrm{Ca}$ as carbonate in place of sulfate forms. However, it has also been reported that assisted water washing produced a permanent effect on sulfate leaching in only a few cases (Astrup, 2007).

In some cases, water washing displays appreciable dissolution yields for $\mathrm{Cu}$, and to some extent $\mathrm{Cr}$ and $\mathrm{Pb}$, although it was also observed that the attained removal is inadequate to reduce leaching below the regulatory limits (Astrup, 2007). The application of assisted water washing using, eg, $\mathrm{CO}_{2}$ to lower the $\mathrm{pH}$ has been reported to allow for the extraction of a number of trace metals including $\mathrm{Cu}, \mathrm{Ni}$, and 


\begin{tabular}{|c|c|c|c|c|}
\hline $\begin{array}{l}\text { Type of } \\
\text { Technology }\end{array}$ & $\begin{array}{l}\text { Type and Number of } \\
\text { Separation Units }\end{array}$ & $\begin{array}{l}\text { Separated Size } \\
\text { Fractions }\end{array}$ & $\begin{array}{l}\text { Target Streams } \\
\text { (and Recovery } \\
\text { Efficiencies) }\end{array}$ & References \\
\hline Dry & $\begin{array}{l}\text { Sieving (2) } \\
\text { Manual sorting (1) } \\
\text { Magnetic separation (3) } \\
\text { Eddy-current separation (1) }\end{array}$ & $\begin{array}{l}>250 \mathrm{~mm} \\
45-250 \mathrm{~mm} \\
<45 \mathrm{~mm}\end{array}$ & $\begin{array}{l}\text { FeM } \\
\text { NFeM (29\%) }\end{array}$ & $\begin{array}{l}\text { Heinrichs et al. } \\
\text { (2012) }\end{array}$ \\
\hline Dry & $\begin{array}{l}\text { Sieving (4) } \\
\text { Magnetic separation (6) } \\
\text { Air classification (1) } \\
\text { Eddy-current separation (3) }\end{array}$ & $\begin{array}{l}>32 \mathrm{~mm} \\
16-32 \mathrm{~mm} \\
6-16 \mathrm{~mm} \\
<6 \mathrm{~mm} \\
\text { (discarded) }\end{array}$ & $\begin{array}{l}\text { Mineral fraction } \\
\text { FeM } \\
\text { NFeM }(75 \%)\end{array}$ & $\begin{array}{l}\text { Heinrichs et al. } \\
\text { (2012) }\end{array}$ \\
\hline Wet & $\begin{array}{l}\text { Sieving (3) } \\
\text { Hydrocycloning (2) } \\
\text { Magnetic separation (1) } \\
\text { Eddy-current separation (3) }\end{array}$ & $\begin{array}{l}>45 \mathrm{~mm} \\
16-45 \mathrm{~mm} \\
4-16 \mathrm{~mm} \\
0.25-4 \mathrm{~mm} \\
<0.25 \mathrm{~mm}\end{array}$ & Mineral fraction & $\begin{array}{l}\text { Holm et al. } \\
(2015)\end{array}$ \\
\hline Dry & $\begin{array}{l}\text { Impact crushing (1) } \\
\text { Manual sorting (1) } \\
\text { Attrition liberation (1) } \\
\text { Sieving (4) } \\
\text { Magnetic separation (5) } \\
\text { Eddy-current separation (4) }\end{array}$ & $\begin{array}{l}>60 \mathrm{~mm} \\
18-60 \mathrm{~mm} \\
5-18 \mathrm{~mm} \\
2-5 \mathrm{~mm} \\
<2 \mathrm{~mm} \\
\text { (discarded) }\end{array}$ & $\begin{array}{l}\text { Mineral fraction } \\
\text { FeM } \\
\text { NFeM } \\
\text { Stainless steel } \\
\text { Metal oxides }\end{array}$ & $\begin{array}{l}\text { Holm et al. } \\
(2015)\end{array}$ \\
\hline Dry & $\begin{array}{l}\text { Sieving (4) } \\
\text { Manual sorting (1) } \\
\text { Attrition liberation (1) } \\
\text { Magnetic separation (5) } \\
\text { Eddy-current separation (4) }\end{array}$ & $\begin{array}{l}>300 \mathrm{~mm} \\
45-300 \mathrm{~mm} \\
8-45 \mathrm{~mm} \\
<8 \mathrm{~mm}\end{array}$ & $\begin{array}{l}\text { Mineral fraction } \\
\text { FeM } \\
\text { NFeM }\end{array}$ & $\begin{array}{l}\text { Holm et al. } \\
\text { (2015) }\end{array}$ \\
\hline Wet & $\begin{array}{l}\text { Wet screening (4) } \\
\text { Hydrocycloning (1) } \\
\text { Washing separation (1) } \\
\text { Thickening (1) } \\
\text { Magnetic separation (1) } \\
\text { Eddy-current separation (1) } \\
\text { Magnus separation (1) }\end{array}$ & $\begin{array}{l}>2 \mathrm{~mm} \\
0.045-2 \mathrm{~mm} \\
<0.045 \mathrm{~mm}\end{array}$ & $\begin{array}{l}\text { Mineral } \\
\text { fractions (sand, } \\
\text { gravel) } \\
\text { NFeM }(58 \%) \\
\mathrm{Al}(67 \%) \\
\mathrm{Cu} / \mathrm{Zn}(38 \%)\end{array}$ & $\begin{array}{l}\text { Rem et al. } \\
(2004)\end{array}$ \\
\hline Dry & $\begin{array}{l}\text { Sieving } \\
\text { Impact separation (Advanced } \\
\text { dry recovery, ADR) (1) } \\
\text { Wind sifting (1) } \\
\text { Magnetic separation } \\
\text { Eddy-current separation }\end{array}$ & $\begin{array}{l}>20 \mathrm{~mm} \\
\text { Others } \\
<2 \mathrm{~mm}\end{array}$ & $\begin{array}{l}\text { Mineral fraction } \\
\text { FeM } \\
\text { Al }(66 \%) \\
\text { NFeM }\end{array}$ & $\begin{array}{l}\text { De Vries et al. } \\
\text { (2012), Hu et al. } \\
\text { (2009) }\end{array}$ \\
\hline Dry & $\begin{array}{l}\text { Sieving (4) } \\
\text { Manual sorting (1) } \\
\text { Magnetic separation (3) } \\
\text { Eddy-current separation (4) } \\
\text { Air classification (2) }\end{array}$ & $\begin{array}{l}>150 \mathrm{~mm} \\
50-150 \mathrm{~mm} \\
10-150 \mathrm{~mm} \\
50-100 \mathrm{~mm} \\
20-50 \mathrm{~mm} \\
4-20 \mathrm{~mm} \\
<10 \mathrm{~mm} \\
<4 \mathrm{~mm}\end{array}$ & $\begin{array}{l}\text { Mineral fraction } \\
\text { FeM } \\
\text { NFeM }\end{array}$ & $\begin{array}{l}\text { Biganzoli et al. } \\
\text { (2013) }\end{array}$ \\
\hline
\end{tabular}




\begin{tabular}{|c|c|c|c|c|}
\hline $\begin{array}{l}\text { Type of } \\
\text { Technology }\end{array}$ & $\begin{array}{l}\text { Type and Number of } \\
\text { Separation Units }\end{array}$ & $\begin{array}{l}\text { Separated Size } \\
\text { Fractions }\end{array}$ & $\begin{array}{l}\text { Target Streams } \\
\text { (and Recovery } \\
\text { Efficiencies) }\end{array}$ & References \\
\hline Wet & $\begin{array}{l}\text { Screening (4) } \\
\text { Wind sifting (1) } \\
\text { Magnetic separation (3) } \\
\text { Eddy-current separation (2) } \\
\text { Magnetic density separation (1) } \\
\text { Jigging (1) } \\
\text { Shaking table separation (1) } \\
\text { Dewatering (1) }\end{array}$ & $\begin{array}{l}>20 \mathrm{~mm} \\
6-20 \mathrm{~mm} \\
2-6 \mathrm{~mm} \\
0.1-2 \mathrm{~mm} \\
<0.1 \mathrm{~mm}\end{array}$ & $\begin{array}{l}\text { Mineral } \\
\text { fractions (sand, } \\
\text { gravel) } \\
\text { FeM }(83 \%) \\
\text { Al }(83 \%) \\
\text { NFeM }(73 \%) \\
\text { HNFeM } \\
\text { Precious metals } \\
\text { Light organics }\end{array}$ & $\begin{array}{l}\text { Hu and Bakker } \\
\text { (2015), } \\
\text { Muchová and } \\
\text { Rem (2006), } \\
\text { Muchova et al. } \\
\text { (2008), Hu and } \\
\text { Rem (2009) }\end{array}$ \\
\hline Wet & $\begin{array}{l}\text { Wet screening (3) } \\
\text { Hydrocycloning (1) } \\
\text { Washing separation (1) } \\
\text { Dewatering (1) } \\
\text { Eddy-current separation (1) } \\
\text { Wet eddy-current separation (2) } \\
\text { Kinetic gravity separation (1) } \\
\text { Magnus separation (1) } \\
\text { Magnetic separation (1) } \\
\text { Density separation (1) }\end{array}$ & $\begin{array}{l}>20 \mathrm{~mm} \\
6-20 \mathrm{~mm} \\
2-6 \mathrm{~mm} \\
0.1-2 \mathrm{~mm} \\
<0.1 \mathrm{~mm}\end{array}$ & 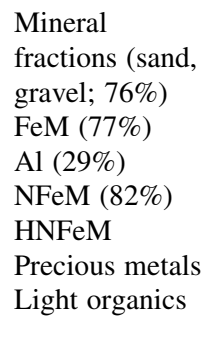 & Muchova (2010) \\
\hline Dry & $\begin{array}{l}\text { Screening (6) } \\
\text { Manual sorting (1) } \\
\text { Magnetic separation (4) } \\
\text { Crushing (1) } \\
\text { Eddy-current separation (3) } \\
\text { Inductive sorting system (1) }\end{array}$ & $\begin{array}{l}>50 \mathrm{~mm} \\
16-50 \mathrm{~mm} \\
8-16 \mathrm{~mm} \\
2-8 \mathrm{~mm} \\
<2 \mathrm{~mm}\end{array}$ & $\begin{array}{l}\text { Mineral fraction } \\
\text { FeM }(85 \%) \\
\text { NFeM }(61 \%) \\
\mathrm{Al}(62 \%) \\
\mathrm{Cu}(61 \%)\end{array}$ & $\begin{array}{l}\text { Allegrini et al. } \\
\text { (2014) }\end{array}$ \\
\hline Dry & $\begin{array}{l}\text { Screening (3) } \\
\text { Magnetic separation (3) } \\
\text { Eddy-current separation (5) } \\
\text { Table separation (3) } \\
\text { Cyclone separation (1) }\end{array}$ & $\begin{array}{l}>5 \mathrm{~mm} \\
0.7-5 \mathrm{~mm} \\
0.1-0.7 \mathrm{~mm} \\
2-8 \mathrm{~mm} \\
<2 \mathrm{~mm}\end{array}$ & $\begin{array}{l}\text { Mineral fraction } \\
\text { FeM }(85 \%) \\
\text { NFeM }(61 \%)\end{array}$ & $\begin{array}{l}\text { Meylan and } \\
\text { Spoerri (2014) }\end{array}$ \\
\hline
\end{tabular}

Zn (Polettini et al., 2005b). On the other hand, although some removal was attained for selected contaminants, $\mathrm{CO}_{2}$-assisted water washing has been observed to have a negative impact on the leaching characteristics, enhancing the release of $\mathrm{Cr}, \mathrm{Cu}$, Mo, and $\mathrm{Ni}$ (Polettini et al., 2005a,b), likely owing to an indirect effect exerted by a decrease in $\mathrm{pH}$.

Other chemical extraction processes have been proposed which involve the use of inorganic acids including hydrochloric, nitric, or sulfuric acid as well as aqua regia, chelating agents including nitrilotriacetate, ethylenediamine-tetraacetate, diethylentriamine-pentaacetate, and saponins, but these have been mainly proposed for fly ash and APC residues for heavy metal recovery and detoxification of the material. Van Gerven et al. (2007) investigated different organic solutions to upgrade BA quality 
and found that $0.2 \mathrm{M}$ ammonium citrate gave the best results in terms of metal removal and leaching of contaminants from the treated material. The extraction process involved one to three extraction steps at $\mathrm{L} / \mathrm{S}=5$ for $1 \mathrm{~h}$ followed by one to three distilled water washing steps at $\mathrm{L} / \mathrm{S}=5$ for $1 \mathrm{~h}$ each to remove the excess of chelating agent. Although three-stage extraction enhanced metal removal from BA, metal leaching from the final residue was not always positively affected by the increase in the extraction steps. Increasing the number of washing stages after extraction was more effective toward improving the leaching behavior of treated BA, and the combination of a single-step extraction with three washing stages using water reduced the leaching of regulated metals below the corresponding Flemish limits.

Other authors (Anjum et al., 2013) studied bioleaching to extract metals from BA using Aspergillus niger metabolites under the combined effect of ultrasonic radiation. The acidic metabolites of the microbial species (particularly citric acid and oxalic acid) promoted the leaching of a number of metals $(\mathrm{Al}, \mathrm{Fe}$, and $\mathrm{Zn}$ ) from the ash matrix.

The environmental burdens of chemical extraction are evident (Reijnders, 2005). Substantial inputs of chemicals are needed for alkaline, acid, and organic extraction. Acid leaching of BA to use the metals is not recommended because substantial amounts of acid are needed to gain a low $\mathrm{pH}$ and high $\mathrm{L} \mathrm{S}^{-1}$, and the leaching/precipitation is a time-consuming, multistage procedure. Furthermore, subsequent selective extraction of the liquid solution for potential recovery of the extracted metals is energy-consuming. When nondegradable chelating agents are applied, the treatment of the residual effluent will be problematic.

\subsubsection{CHEMICAL PROCESSES}

A number of BA processing options involve some level of chemical alteration of the solid matrix. The chemical reactions involved may bind and immobilize specific elements, but may also solubilize others. These chemical reactions may either occur naturally upon interaction with the environment or be purposely induced as a part of an industrial process.

The principle of chemical treatment of BA stems from consideration of the material's chemical reactivity (particularly under alkaline conditions), which has been well documented by several studies (Meima and Comans, 1999; Johnson et al., 1995; Meima and Comans, 1997; Zevenbergen et al., 1996, 1998; Zevenbergen and Comans, 1994; Comans and Meima, 1994). This results from the fact that the high-temperature solids formed during the combustion process become thermodynamically unstable as soon as BA is readily cooled from the furnace temperatures down to ambient conditions during quenching. The complex series of chemical and mineralogical transformations that arise is referred to as natural weathering and is composed of numerous interrelated processes such as hydrolysis, hydration, dissolution/precipitation, carbonation, complexation with organic and inorganic ligands, oxidation/reduction, surface complexation, surface (co)precipitation, sorption, ion exchange, formation of solid solutions, and others (Sabbas et al., 2003).

The purpose of chemical processing of BA is to intentionally induce and accelerate the natural alteration processes of the major mineral phases of the material simultaneously so that adequate stabilization is attained within technically reasonable time frames of hours to weeks or months. Chemical processing may be applied as a pretreatment before use or final disposal. When use is the intended destination for BA, chemical treatments are applied to allow for the development of engineering properties and leaching characteristics that render BA more suited for the application in 
mind. In the case of landfill disposal, chemical processing of BA may still be applied for the material to attain the "final storage quality" (Hjelmar, 1996) before landfilling, thus minimizing the technical requirements for leachate collection and treatment (Sabbas et al., 2003).

In the following, the mechanisms involved in the main chemical processes available for BA are critically reviewed, to derive a comparison of the results that can be obtained from application of the different treatment methods.

\subsubsection{Natural Aging and Weathering}

Natural aging of BA by means of stockpiling under atmospheric conditions is considered to be a costeffective and simple stabilization treatment step to be applied, possibly in combination with additional processing, before use or disposal. For this reason, a stockpiling period of a couple of weeks to several months before use is typical practice in several countries (see e.g. Astrup, 2007).

Weathering reactions proceed naturally in incinerator BA upon contact with atmospheric agents including water, $\mathrm{O}_{2}$ and $\mathrm{CO}_{2}$, and basically mimic the mineralogical alteration processes documented for soils of volcanic origin (Zevenbergen and Comans, 1994; Zevenbergen et al., 1998). Although it is well established that natural weathering leads to the formation of thermodynamically stable phases or phase assemblages (Meima and Comans, 1999; Johnson et al., 1995; Meima and Comans, 1997; Zevenbergen et al., 1996, 1998; Zevenbergen and Comans, 1994; Meima and Comans, 1998; Comans and Meima, 1994; Pfrang-Stotz et al., 2000), completion of the chemical and mineralogical transformations is expected to occur within time frames on the order of hundreds to thousands of years. Nevertheless, it has been shown that a certain degree of BA stabilization can be attained when the material is stockpiled for periods ranging from some weeks to a few months. Within such relatively short periods, mineralogical alterations and $\mathrm{pH}$ changes may modify the leaching-controlling mechanisms altering the release of major ions and trace elements from BA.

However, a number of studies still indicate that stockpiling is not always adequate for the quality standards required for BA use to be attained, which implies the need for additional treatment for specific contaminants (eg, $\mathrm{Cu}, \mathrm{Cr}, \mathrm{Mo}$ ).

Natural weathering may also induce the formation of cementitious phases, which act as binders and confer BA improved mechanical properties (compressive strength and elasticity modulus). This has been observed to occur particularly in the short term (first 2 weeks of aging) and has been ascribed to the presence of portlandite (Chimenos et al., 2005). For longer weathering periods, when ettringite and amorphous $\mathrm{Al}$ (hydr)oxides become the most relevant neo-formed phases along with minor amounts of gypsum, calcite, and Ca silicate aluminate hydrates, mechanical properties are only slightly improved. Compaction of freshly quenched BA before natural weathering also can affect mechanical behavior, improving stiffness and compressive strength (Chimenos et al., 2005). However, detrimental effects, including the formation of gel from the oxidation of metallic aluminum at high $\mathrm{pH}$ and concurrent hydrogen gas evolution, as well as ettringite formation and hydration of $\mathrm{Ca}$ and $\mathrm{Mg}$ oxides, may cause BA expansion phenomena. Typically, the largest volume increase is observed during the first days of weathering and is mainly due to lime hydration.

A number of authors (Freyssinet et al., 2002; Piantone et al., 2004; Pfrang-Stotz et al., 2000) investigated the fate of major elements during short-term natural aging of $\mathrm{BA}$ and concluded that the main mineralogical transformations include hydration of oxides $\left(\mathrm{CaO}, \mathrm{MgO}\right.$, and $\left.\mathrm{Al}_{2} \mathrm{O}_{3}\right)$, precipitation of $\mathrm{Ca}$ carbonates such as calcite and vaterite, formation of $\mathrm{Ca}$ silicate hydrates, conversion of anhydrite into various sulfate forms (bassanite, ettringite, and gypsum), as well as progressive transformation of 
crystalline Fe species (from magnetite to maghemite to hematite). Additional mineral phases have also been identified during natural weathering of BA, including metal oxides, oxy-hydroxides, quartz, and oxalates, as well as zeolite species and aluminum hydroxides polymorphs (bayerite-gibbsite-nordstrandite) (Meima and Comans, 1999, 1997a; Piantone et al., 2004; Zevenbergen et al., 1996). The relative amount of these phases is related both to the duration of the aging period and the extent of contact between solid particles and atmospheric agents.

The occurrence of exothermic reactions during weathering results in temperature changes of BA that may also affect the kinetics of other processes. During BA maturation in heaps, temperature has been observed to range from 15 to $20^{\circ} \mathrm{C}$ higher than ambient temperature to even higher temperature differentials, up to $40^{\circ} \mathrm{C}$ (Freyssinet et al., 2002).

BA maturation also involves organic matter degradation, but neither methane nor organohalogenated compounds or volatile organic compounds (VOCs) were identified, probably because of the low TOC content of BA. However, the occurrence of organic matter biodegradation is indicated by the $\mathrm{O}_{2}$ depletion over time, as observed by a number of authors (Freyssinet et al., 2002).

Investigation of leaching of major ions indicates a rapid washout of chlorides, a reduction in $\mathrm{Ca}$ leaching owing to the changes in the corresponding solubility-controlling species, as well as prolonged leaching of sulfates (Meima and Comans, 1999; Freyssinet et al., 2002; Baranger et al., 2002). An initial increase in the release of $\mathrm{Na}, \mathrm{K}$, and $\mathrm{Mg}$ may also be observed, which is likely related to chloride mobilization, cation exchange mechanisms, or dissolution of aluminosilicate minerals (Zevenbergen and Comans, 1994). In experiments by Freyssinet and colleagues (Freyssinet et al., 2002), dissolution of $\mathrm{NaCl}, \mathrm{KCl}$, and $\mathrm{MgCl}_{2}$ was relatively rapid, so that about $80 \%$ of the chloride species was dissolved within a stockpiling period of 5 months, whereas Meima and Comans (1999) observed low leaching of $\mathrm{Na}, \mathrm{K}$, and chlorides for aging periods longer than 6 weeks. However, the results from Pfrang-Stotz and coworkers (Pfrang-Stotz et al., 2000) disagreed with such findings, because they indicated no significant changes in $\mathrm{K}$ and chloride leaching after 3-month weathering compared with fresh BA.

Leaching of $\mathrm{Ca}$ was reported to be controlled initially by portlandite (Freyssinet et al., 2002; Chimenos et al., 2003); for longer aging periods, gypsum, and ettringite controlled Ca leaching, with a decrease in Ca release resulting in the lower solubility of such phases compared with portlandite; at later stages of weathering, calcite becomes the solubility-controlling mineral for $\mathrm{Ca}$ (Meima and Comans, 1997).

Changes in Ca-controlling phases are reflected by $\mathrm{pH}$ evolution over time, with a decrease in $\mathrm{pH}$ as soon as portlandite is converted into other minerals. However, $\mathrm{pH}$ changes also depend on particle size. Chimenos et al. (2003) observed that whereas larger gravel particles ( $>6 \mathrm{~mm}$ ), which typically have lower $\mathrm{Ca}$ contents, had an initial $\mathrm{pH}$ of $<11$, which was not appreciably affected by weathering, smaller gravel particles $(2-6 \mathrm{~mm})$ had an initial $\mathrm{pH}$ of about 12 and decreased to approximately 11.3 within the first 4 weeks of aging, and then further to about 10 after 3 months. Surprisingly, the study also showed that the 2-mm undersize fraction displayed some slight decrease in $\mathrm{pH}$ after only 4 months of stockpiling; this disagrees with other findings of Arickx et al. (2006), which indicated a decrease in $\mathrm{pH}$ from 12.1 to 10.7 for the BA sand fraction $(0.1-2 \mathrm{~mm})$ after 3 months of natural weathering.

Sulfates are reported to be retained over longer time scales compared with other species, and leaching has been observed to be governed by either ettringite or gypsum, depending on the degree of weathering. The increase in sulfate leaching over time observed by some investigators is likely related to the progressive dissolution of ettringite caused by carbonation, because sulfate concentrations as 
high as $1000 \mathrm{mg} \mathrm{L}^{-1}$ were measured in the leachate from 15- to 18-month stockpiled BA (Freyssinet et al., 2002; Baranger et al., 2002).

The kinetics of $\mathrm{Si}$ minerals dissolution from weathered BA is slowed by the precipitation of secondary silicate phases at alkaline $\mathrm{pH}$; Si leaching decreases over time during natural weathering, likely because of the transition of unstable minerals to more stable (crystalline) phases (Freyssinet et al., 2002). However, it was reported (Chimenos et al., 2003) that for appreciable changes in Si (and $\mathrm{Al})$ mobility from BA to occur, weathering periods of more than 2 weeks are required.

Changes in mineralogical composition and major ions leaching from BA during natural weathering have variously been reported to alter heavy metal mobility. Reductions in $\mathrm{Zn}, \mathrm{Cu}, \mathrm{Pb}$, $\mathrm{Cr}$, and $\mathrm{Ni}$ release were observed during 3-month stockpiling (Meima and Comans, 1997a; Arickx et al., 2006; Pfrang-Stotz et al., 2000). Some authors (Freyssinet et al., 2002) indicated that among various mineral phases, carbonates are responsible for $\mathrm{Pb}$ and $\mathrm{Zn}$ entrapment; other neo-formed phases such as oxides, phosphates, and sulfates may also display some metal-bearing capacity with respect to $\mathrm{Cr}, \mathrm{As}$, and $\mathrm{Pb}$. The occurrence of heavy metals in solid solutions with newly formed minerals (such as calcite) may also have a role (Piantone et al., 2004).

Natural weathering has been found to reduce the leaching of $\mathrm{Pb}$ and $\mathrm{Zn}$ below the limits established by the Flemish regulation for the use of granular materials in construction applications (Arickx et al., 2006), and some studies even report leachate concentrations below the analytical detection limits (Meima and Comans, 1999).

Although $\mathrm{Cu}$ leaching is positively affected by natural aging, $\mathrm{Cu}$ has been reported to be a critical element in view of BA use. Changes in $\mathrm{Cu}$ leaching over time have been related to both $\mathrm{pH}$ changes and organic matter degradation (Meima and Comans, 1997; Arickx et al., 2006), which also occurs to various degrees depending on the particle size as a function of the initial TOC content. It was shown that, although after 3-month aging the gravel fraction of BA complied with the Flemish limits for $\mathrm{Cu}$ in view for use, the sand fraction still displayed unacceptable $\mathrm{Cu}$ release (Arickx et al., 2006), presumably due to the high residual DOC concentrations in the material.

For typical oxyanion-forming metals ( $\mathrm{Cr}, \mathrm{Mo}$, and $\mathrm{Sb}$ ), natural weathering appears to exert mainly a mobilization effect, although the governing mechanisms have not been yet fully elucidated.

\subsubsection{Forced Carbonation}

Carbonation of BA has a major role in modifying the mineralogical characteristics and leaching behavior of BA. Whereas carbonation occurs naturally during weathering, accelerated carbonation has also been studied as an efficient method to control the leaching behavior of some metal contaminants, although it may also have some contrasting effects, depending on the contaminant of concern (see subsequent discussion).

Macroscopically, the effect of carbonation is a general decrease in $\mathrm{pH}$ from the initial alkaline range typical of fresh BA (about 10.5-11.5) to values (about 8.3 ) dictated by $\mathrm{pH}$ control by calcite (Meima et al., 2002; Polettini and Pomi, 2004; Arickx et al., 2006; Polettini et al., 2005b; Baciocchi et al., 2010; Cornelis et al., 2006, 2012). Changes in pH reflect a number of mineralogical alterations, with new mineral phases being formed and others disappearing. Calcite precipitation leads to decreased $\mathrm{Ca}$ leaching owing to the lower solubility of Ca carbonate forms compared with ettringite, which typically governs the leaching behavior of $\mathrm{Ca}$ from freshly quenched BA. Ettringite dissolution upon carbonation has also been proposed as the reason for the increased release of sulfate from carbonated BA (Meima et al., 2002; Polettini and Pomi, 2004; Bodénan et al., 2000; Fernández Bertos et al., 2004). 
As for the other major elements, $\mathrm{Al}$ is known to precipitate mainly as amorphous $\mathrm{Al}(\mathrm{OH})_{3}, \mathrm{Si}$ as amorphous aluminosilicates, and sulfate as gypsum or anhydrite (Meima and Comans, 1999, 1997a; Meima et al., 2002; Dijkstra et al., 2006b).

The influence of accelerated carbonation on trace contaminant leaching from MSWI BA has been the subject of several literature studies. In general, the overall effect of carbonation is the result of multiple mechanisms, including $\mathrm{pH}$ changes, precipitation of metal carbonates, and interaction with newly formed minerals, which in turn depend on both carbonation conditions and the mineralogy of the starting material. In the examined literature studies, different leaching test methods were applied, with the consequence that the mechanisms affecting leaching are accounted for differently, which complicates the interpretation of the experimental results in general terms. A schematic overview of the ranking of the effects of carbonation on contaminant mobility from BA as observed in various experimental studies is provided in Table 24.6.

\subsubsection{Chemical Binding}

Most chemical processes studied for BA treatment aim to decrease the mobility of (mainly) trace metals and are therefore regarded as stabilization processes. The principle of chemical stabilization is to induce the formation of low-solubility mineral phases which possess thermodynamic and geochemical stability under either use or disposal conditions.

Among the chemical binding processes which deserve major attention, the addition of chemical additives capable of increasing the sorptive properties of BA promotes the immobilization of trace metals.

The use of $\mathrm{Al}(\mathrm{III})$ and $\mathrm{Fe}(\mathrm{III})$ salts and other sorbing compounds (steel slag, apatite, allophane, and bauxite) was tested with the aim of reducing the leaching of trace metals from BA (Meima and Comans, 1998; Polettini et al., 2005b; Comans et al., 2000), because of their recognized role in trace contaminant binding, especially for weathered BA (see earlier discussion). Pure Al(III) and Fe(III) salts were capable of immobilizing cationic metals (Cu) (Comans et al., 2000) and oxyanion-forming metals (Mo, Cr, and Sb) (Meima and Comans, 1998; Polettini et al., 2005b). As expected, metal binding was found to be $\mathrm{pH}$ dependent; neutral to alkaline $\mathrm{pHs}$ favored cations whereas lower values favored (oxy)anions. However, a concomitant mobilization effect was observed for other trace metals such as $\mathrm{Ni}$ and $\mathrm{Zn}$, and also for a number of major cations including $\mathrm{Ca}, \mathrm{Mg}$, and $\mathrm{Na}$ (Polettini et al., 2005b). It should be noted that the addition of $\mathrm{Al}$ (III) and Fe(III) salts does also imply an increased leaching of chlorides or sulphates since these salt are mainly added in the form of $\mathrm{Al}$ or Fe chloride or sulphate.

Other authors (Crannell et al., 2000; Polettini et al., 2005b) studied the addition of soluble phosphate to reduce trace metal leaching from BA. Stabilization treatment produced a strong reduction in leaching of $\mathrm{Pb}$ and $\mathrm{Cu}$ and had a positive (although less relevant) effect on $\mathrm{Cd}$ and $\mathrm{Zn}$ (Polettini et al., 2005b). Leaching curves as a function of $\mathrm{pH}$ for phosphate-treated BA were below those of the untreated material for $\mathrm{Cd}, \mathrm{Cu}, \mathrm{Ni}, \mathrm{Zn}$, and $\mathrm{Mo}$, confirming the stability of the corresponding solubilitycontrolling minerals under varying $\mathrm{pH}$ conditions. However, a mobilization effect of the applied process toward $\mathrm{Pb}$ was observed (Polettini et al., 2005b).

\subsubsection{THERMAL PROCESSES}

Thermal techniques involve heating the ashes to about $1000-1500^{\circ} \mathrm{C}$ to promote changes in the physical and chemical characteristics. In most cases, thermal processing give the treated material improved characteristics in view of both use and final disposal. Final products have a reduced volume 


\begin{tabular}{|c|c|c|c|}
\hline Contaminant & Leaching Test Method & Effect & References \\
\hline \multicolumn{4}{|l|}{ Metals } \\
\hline \multirow[t]{3}{*}{$\mathrm{Ba}$} & EN 12457 (LS 10) & $\sim$ & Bodénan et al. (2000) \\
\hline & EN 12457 (LS 10) & $\downarrow$ & Arickx et al. (2006), Van Gerven et al. (2005) \\
\hline & NEN 7343 (column) & $\downarrow$ & Arickx et al. (2006) \\
\hline $\mathrm{Cd}$ & EN 12457 (LS 10) & $\downarrow$ & Rendek et al. (2006) \\
\hline \multirow[t]{6}{*}{$\mathrm{Cr}$} & EN 12457 (LS 10) & $\uparrow$ & $\begin{array}{l}\text { Bodénan et al. (2000), Van Gerven et al. (2005), Rendek } \\
\text { et al. (2006b) }\end{array}$ \\
\hline & EN 12457 (LS 2) & $\uparrow$ & Polettini et al. (2005b) \\
\hline & EN 12457 (LS 10) & $\sim$ & Polettini et al. (2005b) \\
\hline & $\begin{array}{l}\text { NT Enviro } 003 \\
\text { (availability) }\end{array}$ & $\downarrow$ & Todorovic and Ecke (2006) \\
\hline & $\begin{array}{l}\text { NT Enviro } 003 \\
\text { (availability) }\end{array}$ & $\sim$ & Todorovic and Ecke (2006) \\
\hline & NEN 7345 (diffusion) & $\downarrow$ & Todorovic and Ecke (2006) \\
\hline \multirow[t]{12}{*}{$\mathrm{Cu}$} & EN 12457 (LS 10) & $\downarrow$ & Arickx et al. (2006), Van Gerven et al. (2005) \\
\hline & EN 12457 (LS 10) & $\sim$ & Bodénan et al. (2000) \\
\hline & NEN 7343 & $\downarrow$ & Arickx et al. (2006) \\
\hline & EN 12457 (LS 2) & $\uparrow$ & Polettini et al. (2005b) \\
\hline & EN 12457 (LS 10) & $\uparrow$ & Polettini et al., 2005b \\
\hline & WTC ANC & $\sim$ & Polettini and Pomi (2004) \\
\hline & $\begin{array}{l}\text { NT Enviro } 003 \\
\text { (availability) }\end{array}$ & $\sim$ & Todorovic and Ecke (2006) \\
\hline & $\begin{array}{l}\text { NT Enviro } 003 \\
\text { (availability) }\end{array}$ & $\sim$ & Todorovic and Ecke (2006) \\
\hline & NEN 7345 (diffusion) & $\downarrow$ & Todorovic and Ecke (2006) \\
\hline & NEN 7345 (diffusion) & $\uparrow$ & Todorovic and Ecke (2006) \\
\hline & - & $\downarrow$ & Meima et al. (2002) \\
\hline & TS 14497 (pH-stat) & $\downarrow$ & Dijkstra et al. (2006b) \\
\hline \multirow[t]{10}{*}{ Mo } & EN 12457 (LS 10) & $\sim$ & Bodénan et al. (2000), Van Gerven et al. (2005) \\
\hline & EN 12457 (LS 10) & $\downarrow$ & Arickx et al. (2006) \\
\hline & NEN 7343 (column) & $\downarrow$ & Arickx et al. (2006) \\
\hline & EN 12457 (LS 2) & $\sim$ & Polettini et al. (2005b) \\
\hline & EN 12457 (LS 10) & $\uparrow$ & Polettini et al. (2005b) \\
\hline & $\begin{array}{l}\text { NT Enviro } 003 \\
\text { (availability) }\end{array}$ & $\downarrow$ & Todorovic and Ecke (2006) \\
\hline & $\begin{array}{l}\text { NT Enviro } 003 \\
\text { (availability) }\end{array}$ & $\sim$ & Todorovic and Ecke (2006) \\
\hline & NEN 7345 (diffusion) & $\downarrow$ & Todorovic and Ecke (2006) \\
\hline & - & $\uparrow$ & Meima et al. (2002) \\
\hline & TS 14497 (pH-stat) & $\downarrow$ & Dijkstra et al. (2006b) \\
\hline \multirow[t]{4}{*}{$\mathrm{Ni}$} & EN 12457 (LS 10) & $\sim$ & Arickx et al. (2006) \\
\hline & NEN 7343 & $\uparrow$ & Arickx et al. (2006) \\
\hline & EN 12457 (LS 2) & $\uparrow$ & Polettini et al. (2005b) \\
\hline & EN 12457 (LS 10) & $\uparrow$ & Polettini et al. (2005b) \\
\hline
\end{tabular}




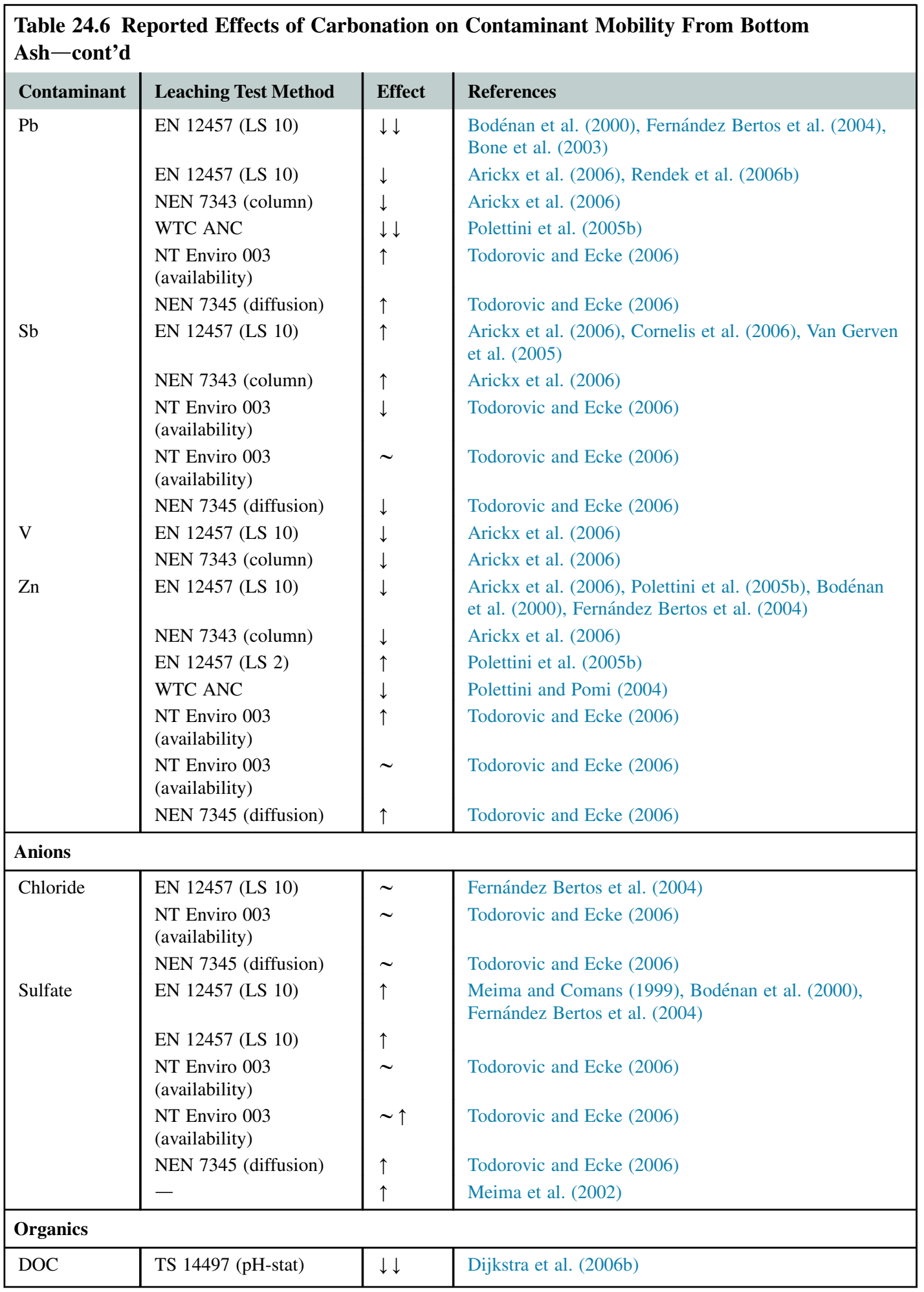


and mechanical properties suitable for engineering applications together with negligible leaching of constituents compared with the original residues (Chandler et al., 1997). Reduced leaching, in particular, is the result of the immobilization of lithophilic metals by means of chemical or physical mechanisms and the removal of volatile compounds as a consequence of vaporization.

The possibility of achieving these goals relies on process variables such as temperature, treatment duration, and the chemical composition of the material to be treated; in particular, this needs to be optimized in terms of the content of glass-formers $\left(\mathrm{SiO}_{2}\right.$ and $\left.\mathrm{Al}_{2} \mathrm{O}_{3}\right)$, melting $\left(\mathrm{Na}_{2} \mathrm{O}\right.$ and $\left.\mathrm{K}_{2} \mathrm{O}\right)$, and stabilizing agents $(\mathrm{CaO}, \mathrm{MgO}, \mathrm{ZnO}$, and $\mathrm{PbO})$, which can be achieved using appropriate additives. The presence of interfering substances such as chlorides, sulfates, and alkalis, is of concern, as well.

Vitrification, melting, and sintering are the major options for thermal treatment, and they differ principally in the characteristics of the treated material rather than the process itself (Chandler et al., 1997; Sabbas et al., 2003).

\subsubsection{Vitrification/Melting}

During vitrification, a mixture of ashes with glass-forming materials and melting/stabilizing oxides is processed at $1000-1500^{\circ} \mathrm{C}$ to form a homogeneous liquid phase. The molten material is then cooled to generate a single-phase glassy product. Virgin materials such as silica and calcium carbonate, or glass scraps may be used as process additives, and their quantity may vary from $20 \%$ to $70 \%$ by weight of the total feed.

Immobilization of contaminants is achieved via chemical bonding and encapsulation mechanisms. Chemical bonding is of concern when considering certain metals (network formers) able to substitute Si-forming covalent bonds with oxygen atoms in the silica network, or ions (network modifiers) able to bind elements of the glass network ionically. Encapsulation occurs during cooling of the molten material, when constituents are surrounded by a glassy layer without chemical interaction with the silica networks (Chandler et al., 1997).

Melting processes are operatively similar to vitrification, but without the addition of glass-forming materials. As a consequence, products from melting are not homogeneous and may contain multiple crystal phases, a separate molten metal phase, or inclusions of unmolten feed. Specific metal phases thus can be separated from the molten product and possibly recycled.

BA vitrification is already a proven treatment technology, mainly owing to its suitable chemical composition. While BA may be thermally treated together with fly ash and APC residues, combined vitrification and melting of both residue types may require previous removal of soluble salts and further treatment of the flue gases.

\subsubsection{Sintering}

Sintering involves heating the ash, either alone or mixed with additives, to temperatures below the melting points of the main constituents, close to those achieved during incineration in the combustion chamber (typically around $900^{\circ} \mathrm{C}$ ). This results in the diffusion transport of material across particle surfaces so that a number of reactions occur between different chemical phases and physical bonding of particles. As a consequence of particle bonding and chemical phase reconfigurations, many constituents are incorporated into a stable matrix.

Thermal treatment at relatively low operating temperatures has the multiple objectives of preventing the loss of volatile species from the material, limiting energy consumption, and reducing 
treatment costs. For such reasons, sintering is probably the most important thermal process for BA. A number of studies have shown application of the process for the production of ceramic materials (Cheeseman et al., 2003; Bethanis, 2004). The perspectives of reusing sintered ash are based on evidence of improvement gained in different important properties upon treatment: The material gains higher strength and density as well as lower porosity, and heavy metal mobility can drastically be reduced.

The process can be implemented in a dedicated unit, eg, in a rotary kiln placed downstream of the combustion chamber or integrated in the combustion unit itself.

\subsubsection{UTILIZATION OPTIONS}

BA may be used in construction either directly as a filler, embankment or foundation material or as an aggregate in other materials such as cement, concrete, or asphalt mixtures. Most research regarding the use of binders to treat BA has been carried out in relation to solidification and stabilization with the purpose of immobilizing the contaminants in a monolithic matrix through chemical stabilization and physical encapsulation. The focus was therefore originally to minimize leaching, but attention has increasing been addressed to the potential use of BA-containing products for construction purposes.

In the following, the most common options and applications for BA use are described.

\subsubsection{Use as Unbound/Bound Aggregate}

BA may be used in construction for different applications mainly involving an aggregate in either unbound or bound forms (ie, added in mixtures with a binder such as cement or asphalt) for the construction of layers of roads, harbor areas, parking lots, and others (Aberg et al., 2006; Dabo et al., 2009; Vegas et al., 2008; Forteza et al., 2004; De Windt et al., 2011; Hjelmar et al., 2007; François and Pierson, 2009; Astrup, 2007) and for the formulation of structural cement or concrete products (Filipponi et al., 2003; Giampaolo et al., 2002; Pecqueur et al., 2001; Cioffi et al., 2011; van der Wegen et al., 2013; Crignon et al., 1999). While unbound applications are well established in several countries such as Denmark, Belgium, Germany, Sweden, Taiwan, The Netherlands, and Japan, the application of BA as an aggregate in concrete products has also gained interest, although the final technical properties of the products may be of concern.

A road is typically constructed of a number of layers of compacted materials, with progressively increasing quality from bottom to top. The layers generally include (from the surface to the lower course) a surface layer (usually made of asphalt), two subsurface layers (a base and a subbase course) made up of either unbound granular compacted materials or cement-bound materials, and a subgrade course, which is the native soil underneath the constructed road. The upper pavement layers are designed to support high, localized loads and are subject to greater wear than the underlying layers. As a result, the use of BA and other recycled aggregates in road construction is usually meant for the lower layers of road pavement (Hill et al., 2001) (the base, or preferably, the subbase courses).

Whereas BA conforms to traditional technical requirements prescribed for the construction of granular road base and subbases courses (Forteza et al., 2004; Becquart et al., 2009), it may fail in fulfilling the requirements prescribed for aggregate in concrete base layers, mainly because of to its poor abrasion resistance (Forteza et al., 2004). 
Concerning the environmental behavior of BA in the constructed road site, the predominant effects are related to the dissolution of salts and associated leaching mainly of $\mathrm{Na}, \mathrm{K}$, and chloride (Aberg et al., 2006; François and Pierson, 2009; Izquierdo et al., 2008; Birgisdóttir et al., 2006). As for metal contaminants, whereas some studies suggest that they are not of environmental concern (François and Pierson, 2009) especially after the initial stage of road operation (Dabo et al., 2009), other researchers (Aberg et al., 2006; Izquierdo et al., 2008) indicated that $\mathrm{Cu}$ and/or $\mathrm{Cr}$ may be leached in higher amounts compared with the use of natural aggregates, and may be problematic in terms of compliance with environmental protection criteria, although it was also noted (De Windt et al., 2011) that the environmental performance of the road is strongly site-specific and may considerably vary from one installation to another. LCA studies on the use of BA in road construction (Birgisdóttir et al., 2006) indicate that the environmental impacts with and without BA are comparable to one another.

As far as BA reuse in bound cement-based forms is concerned, a major challenge is the potential for swelling of structures containing BA, with associated extensive cracking or formation of pop-outs (Pecqueur et al., 2001; Crignon et al., 1999; Alkemade et al., 1994; Müller and Rübner, 2006; Saikia et al., 2015). Such expansion has been associated with the oxidation of metallic aluminum (resulting in the generation of hydrogen gas and an increase in volume) and the formation of ettringite (through the reaction of calcium sulfates, calcium oxides, aluminum oxides, and water, resulting in a mineral of increased volume), hydration of lime and magnesium oxide (resulting in an increase in volume), and alkali-silica reactions (reaction of alkali hydroxides from cement with silica from the glassy particles in the BA, generating a swelling gel). Aluminum oxidation appears to be more important with respect to the expansion of BA mixed in cement and concrete applications (Pecqueur et al., 2001; Crignon et al., 1999; Müller and Rübner, 2006; Saikia et al., 2015). Removal or inactivation of metallic aluminum has been suggested as a potential option to overcome these swelling effects. Metallic aluminum may be oxidized by immersing the BA in an alkaline solution (Pera et al., 1997; Alkemade et al., 1994; Saikia et al., 2015) or by wet grinding (Bertolini et al., 2004). Improved removal of Al particles by eddy current separation is also a possibility. Aging and exposure to atmospheric air have been shown to decrease the reactivity of metallic $\mathrm{Al}$ in incineration ashes (Laenen et al., 2002; Ginés et al., 2009).

Besides the problem of expansion, the overall physical and mechanical quality of cement/concrete mixtures containing BA is lower than that of cement/concrete mixtures with natural aggregate: lower compressive and flexural strength (Pera et al., 1997; Dyer et al., 2000; Paine et al., 2000; Juric et al., 2006), higher water absorption (Pera et al., 1997; Dyer et al., 2000), and lower performance with respect to freeze-thaw cycles (Dyer et al., 2000). In many cases, however, the technical properties of the cementitious products still meet the required prescriptions. On the other hand, by appropriately controlling BA properties including particle density, metallic Al content, sulfate and alkali concentration, and loss on ignition, high-performance products can be obtained (van der Wegen et al., 2013; Keulen et al., 2016). In other cases, it may be possible to find less demanding applications for the produced construction materials, eg, specific lightweight concrete and other low-strength materials (Halliday and Dhir, 2002; Qiao et al., 2008).

Although the use of BA in cement-based applications is essentially a solidification/stabilization technique, leaching of heavy metals often remains a problem. Cai et al. (2004) reported that leaching from concrete-bound BA increased, compared with the reference concrete sample, by a factor of 50 for $\mathrm{Cu}$ and a factor of five for $\mathrm{Cd}, \mathrm{Pb}$, and $\mathrm{Zn}$, whereas no increase was observed for $\mathrm{Cr}$ and $\mathrm{Ni}$. Other 
authors (Tang et al., 2015; Saikia et al., 2015; Jansegers, 1997) reported that whereas the leaching of most contaminants is maintained well below the regulatory limits, $\mathrm{Cu}, \mathrm{Cr}$, Mo, $\mathrm{Sb}, \mathrm{Se}$, chloride, and sulfate may be problematic, probably because of the negative influence of the fine BA fraction on the hydration process of cement (Tang et al., 2015). Soluble salts have another leaching problem: K, Na, chloride, and sulfate cannot be immobilized by the hydrate system and are readily released by leaching (Dyer et al., 2000; Cai et al., 2004). Leaching of salts during the life cycle of the product is unwanted because it increases porosity, decreasing strength, and it leads to salt precipitates on the monolith surface, which often poses aesthetic problems. Again, for dedicated purposes the leaching problem should be remediable through pretreatment.

\subsubsection{Use as a Pozzolanic Admixture}

In principle, considering the typical relative content of the major oxides $\mathrm{SiO}_{2}, \mathrm{CaO}$, and $\mathrm{Al}_{2} \mathrm{O}_{3}, \mathrm{BA}$ may display some pozzolanic behavior in the presence of $\mathrm{Ca}(\mathrm{OH})_{2}$. However, the pozzolanic activity of raw BA is low compared with other typical pozzolanic materials including coal fly ash and silica fume. This is likely the result of the mineralogical characteristics of the amorphous silicate and aluminosilicate phases in BA, the structure of which is probably not easily broken up by the $\mathrm{OH}^{-}$ions released by portlandite. Some researchers have focused on activating BA with different methods (mechanical, chemical, or thermal activation) to improve the pozzolanic properties, to use BA as a substitute for other pozzolanic admixtures (Polettini et al., 2009, 2005; Bertolini et al., 2004; Lin et al., 2008; Lin and Lin, 2006). Among the chemical activation methods investigated, it appears that the use of $2 \% \mathrm{CaCl}_{2}$ results in improved mechanical properties of Portland cement-BA mixtures, whereas Na- and K-based activators do not seem to be capable of producing similar strength enhancement (Polettini et al., 2005b, 2009). However, it is highly probable that the efficacy of a given chemical activation method depends on the specific mineralogical properties of BA. Thermal activation also enhanced the chemical reactivity of BA in cementitious systems, with sintering and vitrification pretreatments promoting pozzolanic reactions (Lin et al., 2008; Lin and Lin, 2006). Another way to improve the pozzolanic properties of BA is to combine it with other incinerator ashes or mineral additions (Bertolini et al., 2004; Cai et al., 2004).

\subsubsection{Use as Aggregate in Asphalt Mixtures}

In the United States, solidification in bituminous structures has been extensively investigated in demonstration projects (Eighmy et al., 1997). In one project, for instance, $7 \%$ of bitumen was blended with an aggregate mix of 50\% natural aggregate and 50\% BA (Musselman et al., 1994). The BA-based pavement was covered by a $2.5-\mathrm{cm}$ wearing surface. After 2 years of field monitoring combined with laboratory testing, it was concluded that the BA-containing mixture had the same physical properties as an asphalt mixture with $100 \%$ natural aggregate, although the first required more bitumen to decrease the porosity of the resulting product (Karpinsky et al., 2000). In a European study (Eymael et al., 1994), between $4.5 \%$ and $6.6 \%$ bitumen and up to $50 \%$ of BA was used. Leaching of inorganic contaminants was below the detection limits for all BA mixtures. Physical tests resulted in a maximum practicable load of 25\% BA. Other authors (Huang et al., 2006) showed that although the technical performance (mainly in terms of durability) of asphalt mixtures to be used in road construction applications worsened in the presence of BA, their environmental behavior was acceptable in terms of both metal leachability and leachate toxicity. A study by Hassan (2005) reported that optimized asphalt mixtures met criteria for use as a bituminous surface or base road courses and satisfied moisture 
susceptibility and raveling potential test limits. Toraldo et al. (2013) showed that stabilized BA could be used in asphalt mixtures for road pavements and fulfilled required specifications for both technical properties and leaching behavior.

\subsection{CONCLUSIONS AND RECOMMENDATIONS}

Although it may appear advisable to pursue the highest level of use of BA, this is not always the most sustainable solution overall. BA processing, treatment, and recycling should be assessed according to a holistic perspective, which in turn should evaluate not only the direct advantages of the intended application, but also the emissions related to the ash treatment itself (and for provision of the energy, resources, materials, etc., used in the treatment processes) as well as potential downstream environmental savings and burdens.

Mechanical separation of metal constituents from BA should be performed in all cases where the environmental value of metal recycling is considerable and the separation process contributes to improving the properties of other ash fractions (for instance, separation of metallic Al which may otherwise be detrimental to the use of the mineral fraction).

Considering that all fractions of the bulk ash materials need to be managed, it may not necessarily be advisable to separate specific size fractions, unless this significantly improves the properties of the remaining material or enhances the recovery of valuable metals. On the other hand, extraction of easily soluble salts may be preferable, because washing with water is a relatively simple process that may be applied directly in the quenching tank and improve the leaching properties of the final BA. Chemical extraction of metals cannot be recommended if the purpose is to stabilize the ashes (because chemical extraction processes often extract only parts of the metal content); however, if the purpose is to recover metals, these processes could be relevant, provided they are selective for the target elements and can be applied at reasonable costs.

As for the stabilization options for the mineral fraction of BA, natural aging may be employed simply by outside storage of the material for several months, which indicates that the benefits of carbonation and weathering can be achieved with relatively little effort. Forced carbonation may facilitate more complete stabilization with a lower final $\mathrm{pH}$ (and thereby potentially lower leaching of some heavy metals); however, careful consideration of the effects on leaching of oxyanions is advised.

Chemical binding of problematic heavy metals may be considered an option in some cases; however, this type of process should generally be considered, eg, combined with washing treatments and not necessarily applicable as a separate option.

Thermal treatment offers the benefits of improved mechanical properties, reduced volume and metal leaching, as well as the destruction of organic compounds. However, thermal techniques also involve significant energy consumption and the potential loss of volatile metals (which emphasizes the need for flue gas treatment and the generation of secondary APC residues) and are generally not economically competitive over other BA-processing options unless high-value products can be obtained.

Enhanced mechanical separation of valuable BA constituents (mineral fraction, FeM, and NFeM) appears to be relatively robust with respect to the achieved separation yield and the degree of purity of the recovered metal fractions. 
Combinations of various processing techniques (eg, mechanical separation and natural weathering combined with specific treatment of individual grain size fractions) may be recommended to improve the technical properties and environmental behavior of BA components, particularly in view of their use.

\section{REFERENCES}

Astrup, T., Dijkstra, J.J., Comans, R.N.J., van der Sloot, H.A., Christensen, T.H., 2006. Geochemical modeling of leaching from MSWI air-pollution-control residues. Environmental Science \& Technology 40, 3551-3557.

Arickx, S., Van Gerven, T., Vandecasteele, C., 2006. Accelerated carbonation for treatment of MSWI bottom ash. Journal of Hazardous Materials 137, 235-243.

Aberg, A., Kumpiene, J., Ecke, H., 2006. Evaluation and prediction of emissions from a road built with bottom ash from municipal solid waste incineration (MSWI). Science of the Total Environment 355, 1-12. http:// dx.doi.org/10.1016/j.scitotenv.2005.03.007.

Arm, M., 2004. Variation in deformation properties of processed MSWI bottom ash: results from triaxial tests. Waste Management 24, 1035-1042. http://dx.doi.org/10.1016/j.wasman.2004.07.013.

Allegrini, E., Maresca, A., Olsson, M.E., Holtze, M.S., Boldrin, A., Astrup, T.F., 2014. Quantification of the resource recovery potential of municipal solid waste incineration bottom ashes. Waste Management 34, 1627-1636. http://dx.doi.org/10.1016/j.wasman.2014.05.003.

Allegrini, E., Vadenbo, C., Boldrin, A., Astrup, T.F., 2015. Life cycle assessment of resource recovery from municipal solid waste incineration bottom ash. Journal of Environmental Management 151, 132-143. http:// dx.doi.org/10.1016/j.jenvman.2014.11.032.

Arickx, S., Van Gerven, T., Knaepkens, T., Hindrix, K., Evens, R., Vandecasteele, C., 2007. Influence of treatment techniques on $\mathrm{Cu}$ leaching and different organic fractions in MSWI bottom ash leachate. Waste Management 27, 1422-1427. http://dx.doi.org/10.1016/j.wasman.2007.03.015.

Arickx, S., De Borger, V., Van Gerven, T., Vandecasteele, C., 2010. Effect of carbonation on the leaching of organic carbon and of copper from MSWI bottom ash. Waste Management 30, 1296-1302. http://dx.doi.org/ 10.1016/j.wasman.2009.10.016.

Astrup, T., 2007. Pretreatment and utilization of waste incineration bottom ashes: Danish experiences. Waste Management 27, 1452-1457. http://dx.doi.org/10.1016/j.wasman.2007.03.017.

Anjum, F., Shahid, M., Bukhari, S., Potgieter, J.H., 2013. Combined ultrasonic and bioleaching treatment of hospital waste incinerator bottom ash with simultaneous extraction of selected metals. Environmental Technology 35, 262-270. http://dx.doi.org/10.1080/09593330.2013.824992.

Alkemade, M.M.C., Eymael, M.M.T., Mulder, E., Wijs, W., 1994. How to prevent expansion of MSWI BA in road constructions? In: Goumans, J.J.J.M., van der Sloot, H.A., Aalbers, T.G. (Eds.), Environmental Aspects of Construction With Waste Materials. Studies in Environmental Science. Elsevier, pp. 863-876. http:// dx.doi.org/10.1016/S0166-1116(08)71517-6.

Bethanis, S., 2004. Effect of sintering temperature on the properties and leaching of incinerator bottom ash. Waste Management \& Research 22, 255-264. http://dx.doi.org/10.1177/0734242X04045426.

Berkhout, S.P.M., Oudenhoven, B.P.M., Rem, P.C., 2011. Optimizing non-ferrous metal value from MSWI bottom ashes. Journal of Environmental Protection (Irvine., Calif) 2, 564-570. http://dx.doi.org/10.4236/jep.2011.25065.

Bayuseno, A.P., Schmahl, W.W., 2010. Understanding the chemical and mineralogical properties of the inorganic portion of MSWI bottom ash. Waste Management 30, 1509-1520. http://dx.doi.org/10.1016/j.wasman. 2010.03.010.

Boesch, M.E., Vadenbo, C., Saner, D., Huter, C., Hellweg, S., 2014. An LCA model for waste incineration enhanced with new technologies for metal recovery and application to the case of Switzerland. Waste Management 34, 378-389. http://dx.doi.org/10.1016/j.wasman.2013.10.019. 
Biganzoli, L., Ilyas, A., van Praagh, M., Persson, K.M., Grosso, M., 2013. Aluminium recovery vs. hydrogen production as resource recovery options for fine MSWI bottom ash fraction. Waste Management 33, 1174-1181. http://dx.doi.org/10.1016/j.wasman.2013.01.037.

Baranger, P., Azaroual, M., Freyssinet, P., Lanini, S., Piantone, P., 2002. Weathering of a MSW bottom ash heap: a modelling approach. Waste Management 22, 173-179. http://dx.doi.org/10.1016/S0956-053X(01)00066-6.

Baciocchi, R., Costa, G., Lategano, E., Marini, C., Polettini, A., Pomi, R., et al., 2010. Accelerated carbonation of different size fractions of bottom ash from RDF incineration. Waste Management 30, 1310-1317.

Bodénan, F., Azaroual, M., Piantone, P., 2000. Forecasting the long-term behaviour of municipal solid waste incineration bottom ash: rapid combined tests. In: Woolley, G.R., Goumans, J.J.J.M., Wainwright, P. (Eds.), Waste Materials in Construction. Waste Managem Ser. Elsevier, pp. 475-482. http://dx.doi.org/10.1016/ S0713-2743(00)80058-6.

Becquart, F., Bernard, F., Abriak, N.E., Zentar, R., 2009. Monotonic aspects of the mechanical behaviour of bottom ash from municipal solid waste incineration and its potential use for road construction. Waste Management 29, 1320-1329. http://dx.doi.org/10.1016/j.wasman.2008.08.019.

Birgisdóttir, H., Pihl, K.A., Bhander, G., Hauschild, M.Z., Christensen, T.H., 2006. Environmental assessment of roads constructed with and without bottom ash from municipal solid waste incineration. Transportation Research Part D: Transport and Environment 11, 358-368. http://dx.doi.org/10.1016/j.trd.2006.07.001.

Bertolini, L., Carsana, M., Cassago, D., Quadrio Curzio, A., Collepardi, M., 2004. MSWI ashes as mineral additions in concrete. Cement and Concrete Research 34, 1899-1906. http://dx.doi.org/10.1016/j.cemconres. 2004.02.001.

Bone, B.D., Knox, K., Picken, A., Robinson, H.D., 2003. The effect of carbonation on leachate quality from landfilled municipal solid waste (MSW) incinerator residues. In: Christensen, T.H., Cossu, R., Stegmann, R. (Eds.), Proc. Sardinia 2003, Ninth Int. Waste Manag. Landfill Symp. CISA, Cagliari, Italy.

Chimenos, J., Fernández, A., Nadal, R., Espiell, F., 2000. Short-term natural weathering of MSWI bottom ash. Journal of Hazardous Materials 79, 287-299. http://dx.doi.org/10.1016/S0304-3894(00)00270-3.

Cheeseman, C.R., Monteiro da Rocha, S., Sollars, C., Bethanis, S., Boccaccini, A.R., 2003. Ceramic processing of incinerator bottom ash. Waste Management 23, 907-916. http://dx.doi.org/10.1016/S0956-053X(03)00039-4.

Crannell, B.S., Eighmy, T.T., Krzanowski, J.E., Eusden, J.D., Shaw, E.L., Francis, C.A., 2000. Heavy metal stabilization in municipal solid waste combustion bottom ash using soluble phosphate. Waste Management 20, 135-148. http://dx.doi.org/10.1016/S0956-053X(99)00312-8.

Cioffi, R., Colangelo, F., Montagnaro, F., Santoro, L., 2011. Manufacture of artificial aggregate using MSWI bottom ash. Waste Management 31, 281-288. http://dx.doi.org/10.1016/j.wasman.2010.05.020.

Chimenos, J., Segarra, M., Fernández, M., Espiell, F., 1999. Characterization of the bottom ash in municipal solid waste incinerator. Journal of Hazardous Materials 64, 211-222. http://dx.doi.org/10.1016/S0304-3894(98) 00246-5.

Cornelissen, G., Gustafsson, Ö., Bucheli, T.D., Jonker, M.T.O., Koelmans, A.A., van Noort, P.C.M., 2005. Extensive sorption of organic compounds to black carbon, coal, and kerogen in sediments and soils: mechanisms and consequences for distribution, bioaccumulation, and biodegradation. Environmental Science \& Technology 39, 6881-6895. http://dx.doi.org/10.1021/es050191b.

Chandler, A.J., Eighmy, T.T., Hjelmar, O., Kosson, D.S., Sawell, S.E., Vehlow, J., et al., 1997. Municipal Solid Waste Incinerator Residues.

Comans, R.N.J., Meima, J.A., 1994. Modelling CA-solubility in MSWI bottom ash leachates. In: Goumans, J.J.J.M., van der Sloot, H.A., Aalbers, T.G. (Eds.), Environ. Asp. Constr. With Waste Mater. Stud. Environ. Sci. Elsevier Science, Amsterdam, pp. 103-110.

Chimenos, J.M., Fernández, A.I., Miralles, L., Rosell, J.R., Ezquerra, A.N., 2005. Change of mechanical properties during short-term natural weathering of MSWI bottom ash. Environmental Science \& Technology 39, 7725-7730. http://dx.doi.org/10.1021/es050420u. 
Chimenos, J.M., Fernández, A.I., Miralles, L., Segarra, M., Espiell, F., 2003. Short-term natural weathering of MSWI bottom ash as a function of particle size. Waste Management 23, 887-895. http://dx.doi.org/10.1016/ S0956-053X(03)00074-6.

Cornelis, G., Van Gerven, T., Vandecasteele, C., 2012. Antimony leaching from MSWI bottom ash: modelling of the effect of $\mathrm{pH}$ and carbonation. Waste Management 32, 278-286. http://dx.doi.org/10.1016/j.wasman. 2011.09.018.

Cornelis, G., Van Gerven, T., Vandecasteele, C., 2006. Antimony leaching from uncarbonated and carbonated MSWI bottom ash. Journal of Hazardous Materials 137, 1284-1292. http://dx.doi.org/10.1016/j.jhazmat. 2006.04.048.

Comans, R.N., Meima, J.A., Geelhoed, P.A., 2000. Reduction of contaminant leaching from MSWI bottom ash by addition of sorbing components. Waste Management 20, 125-133. http://dx.doi.org/10.1016/S0956053X(99)00311-6.

Crignon, C., Pecqueur, G., Diaz, E.G., Germaneau, B., Siwak, J.M., 1999. Study of cement-treated MSWI bottom ash expansion. In: Mehu, J., Keck, G., Navarro, A. (Eds.), Proc. STAB ENV 99, Int. Conf. Waste Stab. Environ. 99. Societé Alpine de Publications, Grenoble, FR, pp. 64-68.

Cai, Z., Bager, D.H., Christensen, T.H., 2004. Leaching from solid waste incineration ashes used in cement-treated base layers for pavements. Waste Management 24, 603-612. http://dx.doi.org/10.1016/j.wasman.2004.01.010.

Chung, Y.-S., Moon, J.-H., Kim, S.-H., Kang, S.-H., Kim, Y.-J., 2007. Determination of the elemental composition of the bottom ash of a municipal incinerator by instrumental neutron activation analysis. Journal of Radioanalytical and Nuclear Chemistry 271, 339-344. http://dx.doi.org/10.1007/s10967-007-0214-1.

Cornelis, G., Johnson, C.A., Van Gerven, T., Vandecasteele, C., 2008. Leaching mechanisms of oxyanionic metalloid and metal species in alkaline solid wastes: a review. Applied Geochemistry 23, 955-976. http:// dx.doi.org/10.1016/j.apgeochem.2008.02.001.

De Vries, W., Rem, P.C., De Keizer, M., 2012. Value creation out of MSWI bottom ash. In: Arm, M., Vandecasteele, C., Heynen, J., Suer, P., Lind, R. (Eds.), Proc. WASCON 2012. Towar. Eff. Durable Sustain. Prod. Use Altern. Mater. Constr. 8th Int. Conf. Sustain. Manag. Waste Recycl. Mater. Constr., Gotheborg (Sweden).

De Windt, L., Dabo, D., Lidelöw, S., Badreddine, R., Lagerkvist, A., 2011. MSWI bottom ash used as basement at two pilot-scale roads: comparison of leachate chemistry and reactive transport modeling. Waste Management 31, 267-280. http://dx.doi.org/10.1016/j.wasman.2010.06.002.

De Wijs, J.W.M., Cleven, R.M.F.J., 2008. Environmental Quality of Stony Construction Materials in The Netherlands.

Dijkstra, J.J., van der Sloot, H.A., Comans, R.N.J., 2006a. The leaching of major and trace elements from MSWI bottom ash as a function of $\mathrm{pH}$ and time. Applied Geochemistry 21, 335-351. http://dx.doi.org/10.1016/ j.apgeochem.2005.11.003.

Dijkstra, J.J., Meeussen, J.C.L., Van der Sloot, H.A., Comans, R.N.J., 2008. A consistent geochemical modelling approach for the leaching and reactive transport of major and trace elements in MSWI bottom ash. Applied Geochemistry 23, 1544-1562. http://dx.doi.org/10.1016/j.apgeochem.2007.12.032.

Dabo, D., Badreddine, R., De Windt, L., Drouadaine, I., 2009. Ten-year chemical evolution of leachate and municipal solid waste incineration bottom ash used in a test road site. Journal of Hazardous Materials 172, 904-913. http://dx.doi.org/10.1016/j.jhazmat.2009.07.083.

Dijkstra, J.J., van der Sloot, H.A., Comans, R.N.J., 2002. Process identification and model development of contaminant transport in MSWI bottom ash. Waste Management 22, 531-541. http://dx.doi.org/10.1016/ S0956-053X(01)00034-4.

Dijkstra, J.J., Van Zomeren, A., Meeussen, J.C.L., Comans, R.N.J., 2006b. Effect of accelerated aging of MSWI bottom ash on the leaching mechanisms of copper and molybdenum. Environmental Science \& Technology 40, 4481-4487. http://dx.doi.org/10.1021/es052214s. 
Dyer, T.D., Dhir, R.K., Collier, T.C., 2000. Precast concrete products produced using incinerator BA. In: Dhir, R.K., Dyer, T.D., Paine, K.A. (Eds.), Proc. Int. Symp. Sustain. Constr. Use Inciner. Ash, pp. 341-353.

European Commission, 2006. Integrated Pollution Prevention and Control. Reference Document on the Best Available Techniques for Waste Incineration.

Eusden, J.D., Eighmy, T.T., Hockert, K., Holland, E., Marsella, K., 1999. Petrogenesis of municipal solid waste combustion bottom ash. Applied Geochemistry 14, 1073-1091. http://dx.doi.org/10.1016/S0883-2927(99) 00005-0.

Eighmy, T.T., Crimi, D., Whitehead, I.E., Zhang, X., Gress, D.L., 1997. The influence of monolith physical properties and integrity on diffusional leaching behavior of asphaltic pavements constructed with MSW combustion BA. In: Goumans, J.J.J.M., Senden, G.J., van der Sloot, H.A. (Eds.), Waste Mater. Constr. Putt. Theory into Pract.. Studies Environmental Science 71, 125-147.

Eymael, M.M.T., de Wijs, W., Mahadew, D., 1994. The use of MSWI BA in asphalt concrete. In: Goumans, J.J.J.M., van der Sloot, H.A., Aalbers, T.G. (Eds.), Environ. Asp. Constr. With Waste Mater. Stud. Environ. Sci., pp. 851-862.

Fruergaard, T., Astrup, T., 2011. Optimal utilization of waste-to-energy in an LCA perspective. Waste Management 31, 572-582. http://dx.doi.org/10.1016/j.wasman.2010.09.009.

Freyssinet, P., Piantone, P., Azaroual, M., Itard, Y., Clozel-Leloup, B., Guyonnet, D., et al., 2002. Chemical changes and leachate mass balance of municipal solid waste bottom ash submitted to weathering. Waste Management 22, 159-172. http://dx.doi.org/10.1016/S0956-053X(01)00065-4.

Filipponi, P., Polettini, A., Pomi, R., Sirini, P., 2003. Physical and mechanical properties of cement-based products containing incineration bottom ash. Waste Management 23, 145-156. http://dx.doi.org/10.1016/S0956053X(02)00041-7.

Forteza, R., Far, M., Seguí, C., Cerdá, V., 2004. Characterization of bottom ash in municipal solid waste incinerators for its use in road base. Waste Management 24, 899-909. http://dx.doi.org/10.1016/j.wasman. 2004.07.004.

François, D., Pierson, K., 2009. Environmental assessment of a road site built with MSWI residue. Science of the Total Environment 407, 5949-5960. http://dx.doi.org/10.1016/j.scitotenv.2009.08.007.

Funari, V., Bokhari, S.N.H., Vigliotti, L., Meisel, T., Braga, R., 2015. The rare earth elements in municipal solid waste incinerators ash and promising tools for their prospecting. Journal of Hazardous Materials 301, 471-479. http://dx.doi.org/10.1016/j.jhazmat.2015.09.015.

Fernández Bertos, M., Simons, S.J.R., Hills, C.D., Carey, P.J., 2004. A review of accelerated carbonation technology in the treatment of cement-based materials and sequestration of $\mathrm{CO}_{2}$. Journal of Hazardous Materials 112, 193-205.

Fujimori, E., Minamoto, K., Iwata, S., Chiba, K., Haraguchi, H., 2004. Enrichment of elements in industrial waste incineration bottom ashes obtained from three different types of incinerators, as studied by ICP-AES and ICPMS. Journal of Material Cycles and Waste Management 6, 73-79. http://dx.doi.org/10.1007/s10163-0030106-6.

Fujimori, E., Minamoto, K., Haraguchi, H., 2005. Comparative study on the distributions of precious metals ( Ru, $\mathrm{Rh}, \mathrm{Pd}, \mathrm{Ir}, \mathrm{Pt}$, and $\mathrm{Au}$ ) in industrial waste incineration ashes as determined by tellurium coprecipitation and ICP-MS. Bulletin of the Chemical Society of Japan 78, 1963-1969. http://dx.doi.org/10.1246/ bcsj.78.1963.

Giampaolo, C., Lo Mastro, S., Polettini, A., Pomi, R., Sirini, P., 2002. Acid neutralisation capacity and hydration behaviour of incineration bottom ash-Portland cement mixtures. Cement and Concrete Research 32, 769-775. http://dx.doi.org/10.1016/S0008-8846(01)00760-8.

Grosso, M., Biganzoli, L., Rigamonti, L., 2011. A quantitative estimate of potential aluminium recovery from incineration bottom ashes. Resources, Conservation and Recycling 55, 1178-1184. http://dx.doi.org/10.1016/ j.resconrec.2011.08.001. 
Ginés, O., Chimenos, J.M., Vizcarro, A., Formosa, J., Rosell, J.R., 2009. Combined use of MSWI bottom ash and fly ash as aggregate in concrete formulation: environmental and mechanical considerations. Journal of Hazardous Materials 169, 643-650. http://dx.doi.org/10.1016/j.jhazmat.2009.03.141.

Hjelmar, O., Holm, J., Crillesen, K., 2007. Utilisation of MSWI bottom ash as sub-base in road construction: first results from a large-scale test site. Journal of Hazardous Materials 139, 471-480. http://dx.doi.org/10.1016/ j.jhazmat.2006.02.059.

Heinrichs, S., Wens, B., Feil, A., Pretz, T., 2012. Recovery of NF-metals from bottom ash's fine fraction - stateof-the-art in Germany. In: Proc. Venice 2012, 4th Int. Symp. Energy From Biomass Waste.

Hu, Y., Bakker, M.C.M., 2015. Recovery of aluminum residue from incineration of cans in municipal solid waste. Journal of Residuals Science \& Technology 12.

Holm, O., Bandow, N., Kalbe, U., Simon, F.G., 2015. Innovative treatment trains of bottom ash (BA) from municipal solid waste incineration (MSWI) in Germany. In: Cossu, R., He, P., Kjeldsen, P., Matsufuji, Y., Reinhart, D., Stegmann, R. (Eds.), Proc. Sardinia 2015, Fifteenth Int. Waste Manag. Landfill Symp. CISA.

Hyks, J., Astrup, T., 2009. Influence of operational conditions, waste input and ageing on contaminant leaching from waste incinerator bottom ash: a full-scale study. Chemosphere 76, 1178-1184. http://dx.doi.org/ 10.1016/j.chemosphere.2009.06.040.

Hyks, J., Astrup, T., Christensen, T.H., 2009. Leaching from MSWI bottom ash: evaluation of non-equilibrium in column percolation experiments. Waste Management 29, 522-529. http://dx.doi.org/10.1016/j.wasman. 2008.06.011.

Hjelmar, O., 1996. Disposal strategies for municipal solid waste incineration residues. Journal of Hazardous Materials 47, 345-368. http://dx.doi.org/10.1016/0304-3894(95)00111-5.

$\mathrm{Hu}$, Y., Rem, P., 2009. Aluminium alloys in municipal solid waste incineration bottom ash. Waste Management \& Research 27, 251-257. http://dx.doi.org/10.1177/0734242X08095564.

Hu, B., Rem, P., van de Winckel, T., 2009. Fine heavy non ferrous and precious metals recovery in bottom ash treatment. In: Proc. ISWA World Congr. 2009, Lisbon (PT).

Hill, A.R., Dawson, A.R., Mundy, M., 2001. Utilisation of aggregate materials in road construction and bulk fill. Resources, Conservation and Recycling 32, 305-320. http://dx.doi.org/10.1016/S0921-3449(01)00067-2.

Halliday, J.E., Dhir, R.K., 2002. Full scale trials using incinerator bottom ash in cement based products. In: Dhir, R.K., Dyer, T.D., Halliday, J.E. (Eds.), Proc. Int. Conf. Challenges Concr. Constr., pp. 429-438.

Huang, C.-M., Chiu, C.-T., Li, K.-C., Yang, W.-F., 2006. Physical and environmental properties of asphalt mixtures containing incinerator bottom ash. Journal of Hazardous Materials 137, 1742-1749. http:// dx.doi.org/10.1016/j.jhazmat.2006.05.016.

Hassan, H.F., 2005. Recycling of municipal solid waste incinerator ash in hot-mix asphalt concrete. Construction and Building Materials 19, 91-98. http://dx.doi.org/10.1016/j.conbuildmat.2004.05.010.

Izquierdo, M., Querol, X., Vazquez, E., 2011. Procedural uncertainties of Proctor compaction tests applied on MSWI bottom ash. Journal of Hazardous Materials 186, 1639-1644. http://dx.doi.org/10.1016/ j.jhazmat.2010.12.045.

Izquierdo, M., Querol, X., Josa, A., Vazquez, E., López-Soler, A., 2008. Comparison between laboratory and field leachability of MSWI bottom ash as a road material. Science of the Total Environment 389, 10-19. http:// dx.doi.org/10.1016/j.scitotenv.2007.08.020.

Johnson, C.A., Brandenberger, S., Baccini, P., 1995. Acid neutralizing capacity of municipal waste incinerator bottom ash. Environmental Science \& Technology 29, 142-147. http://dx.doi.org/10.1021/es00001a018.

Juric, B., Hanzic, L., Ilić, R., Samec, N., 2006. Utilization of municipal solid waste bottom ash and recycled aggregate in concrete. Waste Management 26, 1436-1442. http://dx.doi.org/10.1016/j.wasman.2005.10.016.

Jansegers, E., 1997. The use of MSWI BA in hollow construction materials. In: Goumans, J.J.J.M., Senden, G.J., van der Sloot, H.A. (Eds.), Waste Mater. Constr. Putt. Theory into Pract. Studies in Environmental Science 71, 431-436. 
Jung, C.-H., Osako, M., 2007. Thermodynamic behavior of rare metals in the melting process of municipal solid waste (MSW) incineration residues. Chemosphere 69, 279-288. http://dx.doi.org/10.1016/ j.chemosphere.2007.03.071.

Kirby, C.S., Rimstidt, J.D., 1993. Mineralogy and surface properties of municipal solid waste ash. Environmental Science \& Technology 27, 652-660. http://dx.doi.org/10.1021/es00041a008.

Karpinsky, S., Zhang, X., Janoo, V., Gress, D., Eighmy, T., 2000. A physical evaluation of municipal solid waste grate ash as an aggregate substitute in asphaltic concrete. In: Dhir, R., Dyer, T.D., Paine, K.A. (Eds.), Proc. Int. Symp. Sustain. Constr. Use Inciner. Ash, pp. 216-226.

Keulen, A., van Zomeren, A., Harpe, A., Aarnink, W., Simons, D.J., Brouwers, H.J.H., 2016. High performance of treated and washed MSWI bottom ash granulates as natural aggregate replacement within earth-moist concrete. Waste Management 49, 83-95. http://dx.doi.org/10.1016/j.wasman.2016.01.010.

Kida, A., Noma, Y., Imada, T., 1996. Chemical speciation and leaching properties of elements in municipal incinerator ashes. Waste Management 16, 527-536. http://dx.doi.org/10.1016/S0956-053X(96)00094-3.

Laenen, B., Dreesen, R., van Rossem, D., 2002. Aggregate cement reactions in MWI-bottom ash-based concrete a petrographical assessment. In: Challenges Concr. Constr.. Sustain. Concr. Constr., vol. 5 Thomas Telford Publishing, pp. 335-344.

Lin, K.L., Chang, W.C., Lin, D.F., 2008. Pozzolanic characteristics of pulverized incinerator bottom ash slag. Construction and Building Materials 22, 324-329. http://dx.doi.org/10.1016/j.conbuildmat.2006. 08.012.

Lin, K.L., Lin, D.F., 2006. Hydration characteristics of municipal solid waste incinerator bottom ash slag as a pozzolanic material for use in cement. Cement \& Concrete Composites 28, 817-823. http://dx.doi.org/ 10.1016/j.cemconcomp.2006.03.003.

Meima, J.A., Comans, R.N., 1999. The leaching of trace elements from municipal solid waste incinerator bottom ash at different stages of weathering. Applied Geochemistry 14, 159-171.

Meima, J.A., Comans, R.N.J., 1998. Application of surface complexation/precipitation modeling to contaminant leaching from weathered municipal solid waste incinerator bottom ash. Environmental Science \& Technology 32, 688-693. http://dx.doi.org/10.1021/es9701624.

Meima, J.A., van der Weijden, R.D., Eighmy, T.T., Comans, R.N., 2002. Carbonation processes in municipal solid waste incinerator bottom ash and their effect on the leaching of copper and molybdenum. Applied Geochemistry 17, 1503-1513. http://dx.doi.org/10.1016/S0883-2927(02)00015-X.

Meima, J.A., Comans, R.N.J., 1997a. Geochemical modeling of weathering reactions in municipal solid waste incinerator bottom ash. Environmental Science \& Technology 31, 1269-1276.

Meima, J., Comans, R.N., 1998. Reducing Sb-leaching from municipal solid waste incinerator bottom ash by addition of sorbent minerals. Journal of Geochemical Exploration 62, 299-304. http://dx.doi.org/10.1016/ S0375-6742(97)00044-7.

Meylan, G., Spoerri, A., 2014. Eco-efficiency assessment of options for metal recovery from incineration residues: a conceptual framework. Waste Management 34, 93-100. http://dx.doi.org/10.1016/j.wasman.2013.10.001.

Meima, J.A., Comans, R.N.J., 1997b. Overview of geochemical processes controlling leaching characteristics of MSWI bottom ash. In: Stud. Environ. Sci. Waste Mater. Constr. - Putt. Theory into Pract. Elsevier, pp. 447-457. http://dx.doi.org/10.1016/S0166-1116(97)80228-2.

Muchová, L., Rem, P.C., 2006. Metal content and recovery of MSWI bottom ash in Amsterdam. WIT Transactions on Ecology and the Environment 92.

Muchova, L., Bakker, E., Rem, P., 2008. Precious metals in municipal solid waste incineration bottom ash. Water, Air, \& Soil Pollution: Focus 9, 107-116. http://dx.doi.org/10.1007/s11267-008-9191-9.

Morf, L.S., Gloor, R., Haag, O., Haupt, M., Skutan, S., Di Lorenzo, F., et al., 2013. Precious metals and rare earth elements in municipal solid waste-sources and fate in a Swiss incineration plant. Waste Management 33, 634-644. http://dx.doi.org/10.1016/j.wasman.2012.09.010. 
Meima, J.A., van Zomeren, A., Comans, R.N.J., 1999. Complexation of $\mathrm{Cu}$ with dissolved organic carbon in municipal solid waste incinerator bottom ash leachates. Environmental Science \& Technology 33, 1424-1429. http://dx.doi.org/10.1021/es971113u.

Milne, C.J., Kinniburgh, D.G., van Riemsdijk, W.H., Tipping, E., 2003. Generic NICA-Donnan model parameters for metal-ion binding by humic substances. Environmental Science \& Technology 37, 958-971. http:// dx.doi.org/10.1021/es0258879.

Muchova, L., 2010. Wet Physical Separation of MSWI Bottom Ash. Technical University Ostrawa, Czech Republic.

Müller, U., Rübner, K., 2006. The microstructure of concrete made with municipal waste incinerator bottom ash as an aggregate component. Cement and Concrete Research 36, 1434-1443. http://dx.doi.org/10.1016/ j.cemconres.2006.03.023.

Musselman, C.N., Killeen, M.P., Crimi, D., Hasan, S., Zhang, X., Gress, D.L., et al., 1994. The Laconia, New Hampshire BA paving project. In: Environ. Asp. Constr. With Waste Mater. Stud. Environ. Sci, p. 60.

Onori, R., Will, J., Hoppe, A., Polettini, A., Pomi, R., Boccaccini, A.R., 2011a. Bottom ash-based geopolymer materials: mechanical and environmental properties. In: Ceram. Eng. Sci. Proc., pp. 71-82.

Onori, R., Polettini, A., Pomi, R., 2011b. Mechanical properties and leaching modeling of activated incinerator bottom ash in Portland cement blends. Waste Management 31, 298-310.

Olsson, S., Kärrman, E., Gustafsson, J.P., 2006. Environmental systems analysis of the use of bottom ash from incineration of municipal waste for road construction. Resources, Conservation and Recycling 48, 26-40. http://dx.doi.org/10.1016/j.resconrec.2005.11.004.

Olsson, S., van Schaik, J.W.J., Gustafsson, J.P., Kleja, D.B., van Hees, P.A.W., 2007. Copper(II) binding to dissolved organic matter fractions in municipal solid waste incinerator bottom ash leachate. Environmental Science \& Technology 41, 4286-4291. http://dx.doi.org/10.1021/es062954g.

Polettini, A., Pomi, R., 2004. The leaching behavior of incinerator bottom ash as affected by accelerated ageing. Journal of Hazardous Materials 113, 209-215.

Piantone, P., Bodénan, F., Chatelet-Snidaro, L., 2004. Mineralogical study of secondary mineral phases from weathered MSWI bottom ash: implications for the modelling and trapping of heavy metals. Applied Geochemistry 19, 1891-1904. http://dx.doi.org/10.1016/j.apgeochem.2004.05.006.

Polettini, A., Pomi, R., Fortuna, E., 2009. Chemical activation in view of MSWI bottom ash recycling in cementbased systems. Journal of Hazardous Materials 162, 1292-1299.

Polettini, A., Pomi, R., Carcani, G., 2005a. The effect of Na and Ca salts on MSWI bottom ash activation for reuse as a pozzolanic admixture. Resources, Conservation and Recycling 43, 403-418.

Pera, J., Coutaz, L., Ambroise, J., Chababbet, M., 1997. Use of incinerator bottom ash in concrete. Cement and Concrete Research 27, 1-5. http://dx.doi.org/10.1016/S0008-8846(96)00193-7.

Pecqueur, G., Crignon, C., Quénée, B., 2001. Behaviour of cement-treated MSWI bottom ash. Waste Management 21, 229-233. http://dx.doi.org/10.1016/S0956-053X(00)00094-5.

Polettini, A., Pomi, R., Ragaglia, M., 2005b. Accelerated ageing as a tool for sustainable disposal of incinerator bottom ash. In: Proc. Sardinia 2005, Tenth Int. Waste Manag. Landfill Symp., CISA (Cagliari, Italy).

Pfrang-Stotz, G., Reichelt, J., Roos, R., 2000. Chemical-mineralogical valuation of the leachate potential of municipal solid waste incineration (MSWI) BA. In: Waste Mater. Constr. Manag. Ser. Elsevier, pp. 975-983. http://dx.doi.org/10.1016/S0713-2743(00)80105-1.

Paine, K.A., Dhir, R.K., Doran, V.P.A., 2000. Unprocessed and processed incinerator BA as a cement bound material. In: Dhir, R.K., Dyer, T.D., Paine, K.A. (Eds.), Proc. Int. Symp. Sustain. Constr. Use Inciner. Ash, pp. 267-278.

Qiao, X.C., Ng, B.R., Tyrer, M., Poon, C.S., Cheeseman, C.R., 2008. Production of lightweight concrete using incinerator bottom ash. Construction and Building Materials 22, 473-480. http://dx.doi.org/10.1016/ j.conbuildmat.2006.11.013. 
Rem, P.C., De Vries, C., van Kooy, L.A., Bevilacqua, P., Reuter, M.A., 2004. The Amsterdam pilot on bottom ash. Minerals Engineering 17, 363-365. http://dx.doi.org/10.1016/j.mineng.2003.11.009.

Rocca, S., van Zomeren, A., Costa, G., Dijkstra, J.J., Comans, R.N.J., Lombardi, F., 2013. Mechanisms contributing to the thermal analysis of waste incineration bottom ash and quantification of different carbon species. Waste Management 33, 373-381. http://dx.doi.org/10.1016/j.wasman.2012.11.004.

Rendek, E., Ducom, G., Germain, P., 2006a. Influence of organic matter on municipal solid waste incinerator bottom ash carbonation. Chemosphere 64, 1212-1218. http://dx.doi.org/10.1016/j.chemosphere.2005.11.053.

Reijnders, L., 2005. Disposal, uses and treatments of combustion ashes: a review. Resources, Conservation and Recycling 43, 313-336. http://dx.doi.org/10.1016/j.resconrec.2004.06.007.

Rendek, E., Ducom, G., Germain, P., 2006b. Carbon dioxide sequestration in municipal solid waste incinerator (MSWI) bottom ash. Journal of Hazardous Materials 128, 73-79. http://dx.doi.org/10.1016/j.jhazmat. 2005.07.033.

van der Sloot, H.A., Kosson, D.S., Hjelmar, O., 2001. Characteristics, treatment and utilization of residues from municipal waste incineration. Waste Management 21, 753-765. http://dx.doi.org/10.1016/S0956-053X(01) 00009-5.

Šyc, M., Kameníková, P., Svoboda, K., Krausová, A., Pohořelý, M., Zach, B., et al., 2015. Resource recovery potential of the bottom ash from municipal solid waste incineration in the Czech Republic. In: Proc. Sardinia 2015, Fifteenth Int. Waste Manag. Landfill Symp.

Sormunen, L.A., Rantsi, R., 2015. To fractionate municipal solid waste incineration bottom ash: key for utilisation? Waste Management \& Research 33, 995-1004. http://dx.doi.org/10.1177/0734242X15600052.

Sabbas, T., Polettini, A., Pomi, R., Astrup, T., Hjelmar, O., Mostbauer, P., et al., 2003. Management of municipal solid waste incineration residues. Waste Management 23, 61-88. http://dx.doi.org/10.1016/S0956-053X(02) 00161-7.

Saveyn, H., Eder, P., Garbarino, E., Muchova, L., Hjelmar, O., van der Sloot, H.A., et al., 2014. Study on Methodological Aspects Regarding Limit Values for Pollutants in Aggregates in the Context of the Possible Development of End-of-Waste Criteria Under the EU Waste Framework Directive. Report EUR 26769 EN.

Saikia, N., Mertens, G., Van Balen, K., Elsen, J., Van Gerven, T., Vandecasteele, C., 2015. Pre-treatment of municipal solid waste incineration (MSWI) bottom ash for utilisation in cement mortar. Construction and Building Materials 96, 76-85. http://dx.doi.org/10.1016/j.conbuildmat.2015.07.185.

Triffault-Bouchet, G., Clément, B., Blake, G., 2005. Ecotoxicological assessment of pollutant flux released from bottom ash reused in road construction. Aquatic Ecosystem Health \& Management 8, 405-414. http:// dx.doi.org/10.1080/14634980500457724.

Tang, P., Florea, M.V.A., Spiesz, P., Brouwers, H.J.H., 2015. Characteristics and application potential of municipal solid waste incineration (MSWI) bottom ashes from two waste-to-energy plants. Construction and Building Materials 83, 77-94. http://dx.doi.org/10.1016/j.conbuildmat.2015.02.033.

Toraldo, E., Saponaro, S., Careghini, A., Mariani, E., 2013. Use of stabilized bottom ash for bound layers of road pavements. Journal of Environmental Management 121, 117-123. http://dx.doi.org/10.1016/j.jenvman. 2013.02.037.

Todorovic, J., Ecke, H., 2006. Demobilisation of critical contaminants in four typical waste-to-energy ashes by carbonation. Waste Management 26, 430-441. http://dx.doi.org/10.1016/j.wasman.2005.11.011.

Van Gerven, T., Cooreman, H., Imbrechts, K., Hindrix, K., Vandecasteele, C., 2007. Extraction of heavy metals from municipal solid waste incinerator (MSWI) bottom ash with organic solutions. Journal of Hazardous Materials 140, 376-381. http://dx.doi.org/10.1016/j.jhazmat.2006.10.037.

Van Gerven, T., Van Keer, E., Arickx, S., Jaspers, M., Wauters, G., Vandecasteele, C., 2005. Carbonation of MSWI-bottom ash to decrease heavy metal leaching, in view of recycling. Waste Management 25, 291-300. http://dx.doi.org/10.1016/j.wasman.2004.07.008. 
Vehlow, J., 2015. Air pollution control systems in WtE units: an overview. Waste Management 37, 58-74. http:// dx.doi.org/10.1016/j.wasman.2014.05.025.

Vehlow, J., 2012. Reduction of dioxin emissions from thermal waste treatment plants: a brief survey. Reviews in Environmental Science and Bio-Technology 11, 393-405. http://dx.doi.org/10.1007/s11157-012-9296-5.

Vegas, I., Ibañez, J.A., San José, J.T., Urzelai, A., 2008. Construction demolition wastes, Waelz slag and MSWI bottom ash: a comparative technical analysis as material for road construction. Waste Management 28, 565-574. http://dx.doi.org/10.1016/j.wasman.2007.01.016.

Wei, Y., Shimaoka, T., Saffarzadeh, A., Takahashi, F., 2011. Mineralogical characterization of municipal solid waste incineration bottom ash with an emphasis on heavy metal-bearing phases. Journal of Hazardous Materials 187, 534-543. http://dx.doi.org/10.1016/j.jhazmat.2011.01.070.

van der Wegen, G., Hofstra, U., Speerstra, J., 2013. Upgraded MSWI bottom ash as aggregate in concrete. Waste and Biomass Valorization 4, 737-743. http://dx.doi.org/10.1007/s12649-013-9255-6.

Yao, J., Li, W., Xia, F., Wang, J., Fang, C., Shen, D., 2010. Investigation of Cu leaching from municipal solid waste incinerator bottom ash with a comprehensive approach. Frontiers in Energy 5, 340-348. http://dx.doi.org/ 10.1007/s11708-010-0131-9.

van Zomeren, A., Comans, R.N.J., 2004. Contribution of natural organic matter to copper leaching from municipal solid waste incinerator bottom ash. Environmental Science \& Technology 38, 3927-3932. http://dx.doi.org/ 10.1021/es035266v.

Zevenbergen, C., van Reeuwijk, L.P., Bradley, J.P., Bloemen, P., Comans, R.N.J., 1996. Mechanism and conditions of clay formation during natural weathering of MSWI bottom ash. Clays and Clay Minerals 44, $546-552$.

Zevenbergen, C., Comans, R.N.J., 1994. Geochemical factors controlling the mobilization of major elements during weathering of MSWI bottom ash. In: Stud. Environ. Sci. Elsevier, pp. 179-194. http://dx.doi.org/ 10.1016/S0166-1116(08)71455-9.

Zevenbergen, C., Van Reeuwijk, L., Bradley, J., Comans, R.N., Schuiling, R., 1998. Weathering of MSWI bottom ash with emphasis on the glassy constituents. Journal Geochemical Exploration 62, 293-298. http:// dx.doi.org/10.1016/S0375-6742(97)00033-2.

van Zomeren, A., Comans, R.N.J., 2009. Carbon speciation in municipal solid waste incinerator (MSWI) bottom ash in relation to facilitated metal leaching. Waste Management 29, 2059-2064. http://dx.doi.org/10.1016/ j.wasman.2009.01.005.

Zwahr, E., 2004. Ash recycling: Just a dream?. In: Proc. 12th Annu. North Am. Waste-to-Energy Conf. (NAWTEC 12), May 17-19 2004, Savannah, Georgia (USA).

Zhang, F.-S., Yamasaki, S., Kimura, K., 2001. Rare earth element content in various waste ashes and the potential risk to Japanese soils. Environment International 27, 393-398. http://dx.doi.org/10.1016/S0160-4120(01) 00097-6.

Zhao, L., Zhang, F.-S., Zhang, J., 2008. Chemical properties of rare earth elements in typical medical waste incinerator ashes in China. Journal of Hazardous Materials 158, 465-470. http://dx.doi.org/10.1016/ j.jhazmat.2008.01.091. 
This page intentionally left blank 


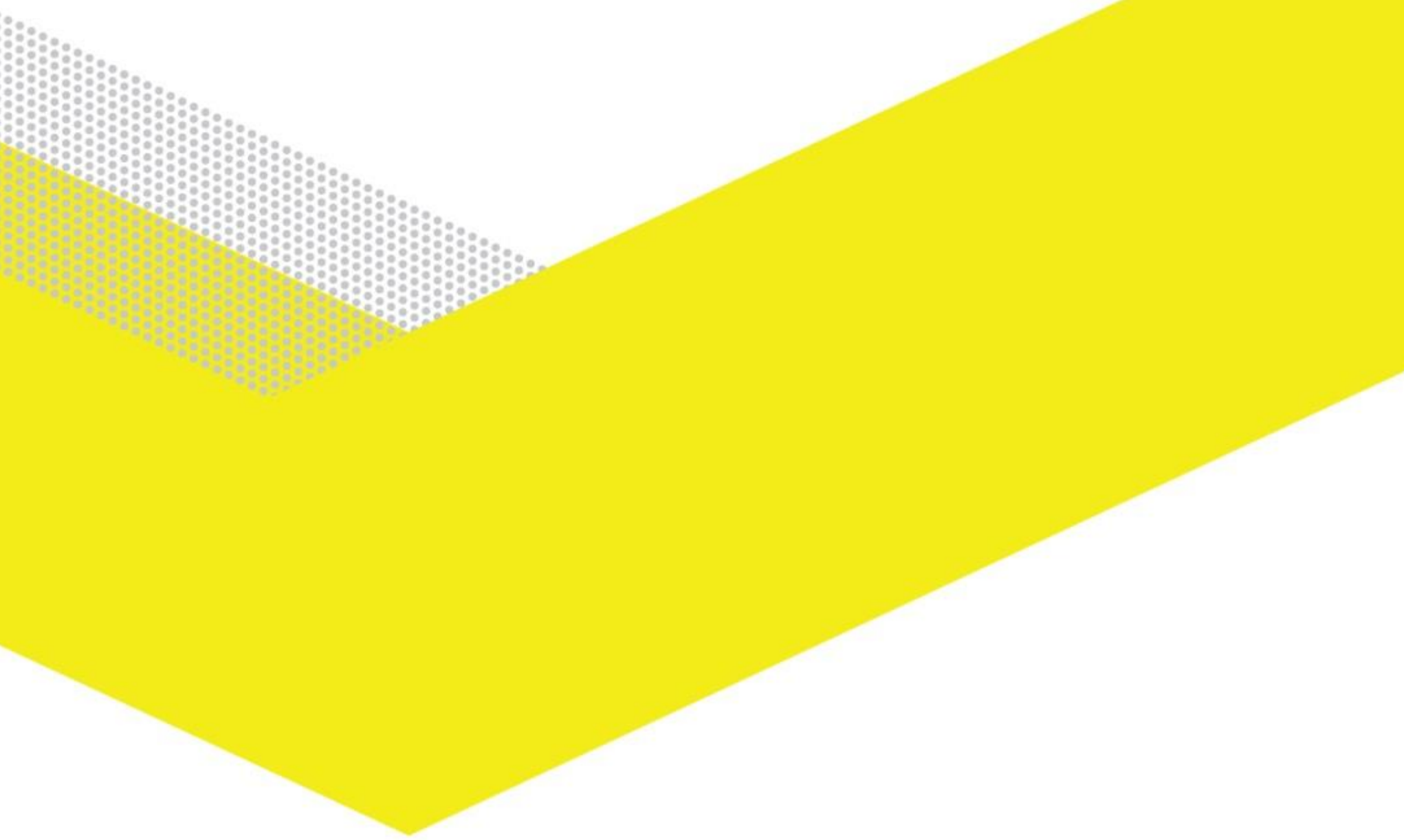

ECN

Westerduinweg 3

P.O. Box 1

1755 LE Petten

1755 ZG Petten

The Netherlands

The Netherlands

$T+31885154949$

$F+31885158338$

info@ecn.nl

www.ecn.nl 